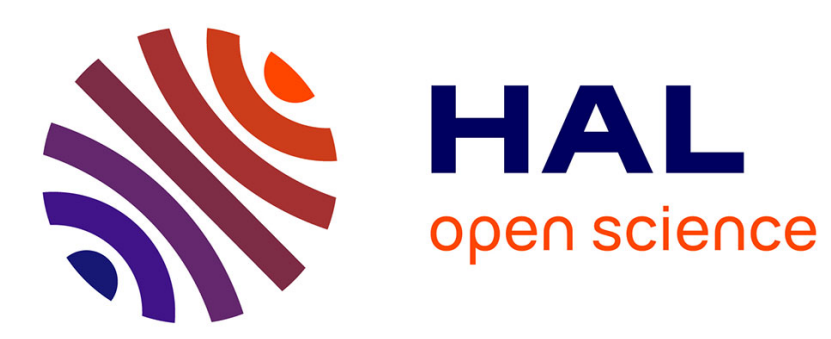

\title{
Variations of $\mathrm{Mg}$ isotope geochemistry in soils over a Hawaiian 4 Myr chronosequence
} Jong-Sik Ryu, Nathalie Vigier, Louis Derry, Oliver Chadwick

\section{To cite this version:}

Jong-Sik Ryu, Nathalie Vigier, Louis Derry, Oliver Chadwick. Variations of Mg isotope geochemistry in soils over a Hawaiian 4 Myr chronosequence. Geochimica et Cosmochimica Acta, 2021, 292, pp.94114. 10.1016/j.gca.2020.09.024 . hal-02991091

\section{HAL Id: hal-02991091 https://hal.science/hal-02991091}

Submitted on 13 Nov 2020

HAL is a multi-disciplinary open access archive for the deposit and dissemination of scientific research documents, whether they are published or not. The documents may come from teaching and research institutions in France or abroad, or from public or private research centers.
L'archive ouverte pluridisciplinaire HAL, est destinée au dépôt et à la diffusion de documents scientifiques de niveau recherche, publiés ou non, émanant des établissements d'enseignement et de recherche français ou étrangers, des laboratoires publics ou privés. 
${ }^{1}$ Department of Earth and Environmental Sciences, Pukyong National University, Busan 48513, South Korea

${ }^{2}$ LOV, CNRS, UPMC, UMR 7093, 181 chemin du Lazaret, 06230 Villefranche-sur-Mer, France

${ }^{3}$ Department of Earth and Atmospheric Science, Cornell University, NY 14853, USA

${ }^{4}$ Department of Geography, University of California, Santa Barbara, CA 93106, USA

Number of tables: 5 including Supplementary Information

Number of figures: 7 including Supplementary Information

Number of words in the abstract: 281

Original version resubmitted to Geochimica et Cosmochimica Acta on August 16, 2019 $3^{\text {rd }}$ revised version submitted to Geochimica et Cosmochimica Acta on September 18, 2020

"Author to whom correspondence should be addressed: Phone (+82-51-6296624), FAX (+82-516296623), and e-mail (jongsikryu@gmail.com) 
ABSTRACT

Magnesium (Mg) isotopes fractionate during rock/mineral weathering and leaching,

47 secondary mineral neoformation, adsorption/desorption, and plant-related $\mathrm{Mg}$ recycling, but the

48 mechanisms and extent of fractionation are not well understood. Here, we report the fate of $\mathrm{Mg}$

49 and its isotopes during weathering and soil development in the Hawaiian Islands by sampling

50 soils of varying age $(0.3,20,150,1,400$, and 4,100 ka) in undisturbed humid rainforests.

51 Magnesium concentrations in bulk soils are variable with depth and age, ranging from 0.07 to

528.79 wt. $\%$, and significant $\mathrm{Mg}$ depletions (up to $99 \%$ ) relative to parent basalts are visible after

$5320 \mathrm{ka}$. Bulk soils display a large age-dependent range of $\delta^{26} \mathrm{Mg}$ values ranging from -0.60 to

$54+0.26 \%$. A sequential leaching scheme showed that labile $\mathrm{Mg}$ is depleted whereas residual $\mathrm{Mg}$ is

55 enriched in isotopically heavy $\mathrm{Mg}$. The two youngest soils (0.3 ka) display $\delta^{26} \mathrm{Mg}$ value similar

56 to basalt for both labile or residual $\mathrm{Mg}$, indicating either that basalt weathering causes little $\mathrm{Mg}$

57 isotope fractionation or that $\delta^{26} \mathrm{Mg}$ value is overwhelmed by the primary minerals during $0.3 \mathrm{ka}$.

58 However, in the older soils ( $\geq 20 \mathrm{ka}$ ), the $\delta^{26} \mathrm{Mg}$ values of both labile and residual $\mathrm{Mg}$ vary non-

59 linearly as a function of time, with an increase in the difference between them. These variations

60 are explained by both plant-related $\mathrm{Mg}$ recycling and progressive mineral transformations,

61 evolving from short-range-order (SRO) minerals (allophane and ferrihydrite) to more crystalline

62 products (goethite, gibbsite and kaolin minerals). Indeed, plant-related $\mathrm{Mg}$ recycling causes the

63 enrichment of light $\mathrm{Mg}$ isotopes in the labile $\mathrm{Mg}$, while crystalline secondary phases incorporate

64 more and more heavy $\mathrm{Mg}$ isotopes with time. These results reconcile experimental and field

65 studies and highlight a weathering control of $\mathrm{Mg}$ isotopes delivered to the oceans.

66

67 Keywords: Magnesium isotopes; Secondary minerals; Isotope fractionation; Basalt weathering;

68 Soil; Hawaii 


\section{INTRODUCTION}

The release of cations, especially calcium $(\mathrm{Ca})$ and magnesium $(\mathrm{Mg})$, from silicate rocks

71 during chemical weathering is one of the most important processes controlling long-term climate

72 change, seawater chemistry and nutrient cycling in soils (Berner et al., 1983; de Villiers and

73 Nelson, 1999; Berner, 2004). Basalt weathering is important in terms of global carbon cycle

74 because it accounts for about $35 \%$ of the global $\mathrm{CO}_{2}$ sink associated with silicate weathering

75 while basalt covers less than $5 \%$ of the overall continental area (Dessert et al., 2003). In parallel,

76 basalt weathering exports considerable amount of major and trace elements, and nutrients to the

77 ocean via river transport (Dessert et al., 2001, 2003).

In this context, non-traditional stable isotopes, such as lithium, calcium, and magnesium

79 isotopes, can be used to trace silicate weathering and reconstructing paleo-climate (e.g., Tipper et

80 al., 2006, 2008a; Vigier et al., 2009; Misra and Froelich, 2012; Pogge von Strandmann et al.,

$812008,2012,2013$; Ryu et al., 2014). However additional work is needed to provide clear

82 linkages between fractionation processes occurring in natural Earth surface systems and those

83 deduced from experimental studies. Many studies indicate that significant $\mathrm{Mg}$ isotope

84 fractionation occurs during rock/mineral dissolution, secondary mineral neoformation,

85 adsorption/desorption, plant uptake/decomposition and recycling (e.g., Tipper et al., 2006,

86 2008a; Black et al, 2008; Pogge von Strandmann et al., 2008; Teng et al., 2010; Wimpenny et al.,

87 2010, 2014; Ryu et al., 2011, 2016; Bolou-Bi et al., 2010, 2012; Huang et al., 2012; Lee et al.,

88 2014; Liu et al., 2014; Opfergelt et al., 2014; Gao et al., 2018). However, reported directions of

$89 \mathrm{Mg}$ isotope fractionation appear contradictory. For example, dissolution experiments show that

90 light $\mathrm{Mg}$ isotopes are preferentially released during primary olivine dissolution (Wimpenny et

91 al., 2010), even as other studies indicate little apparent $\mathrm{Mg}$ isotope fractionation between solution 
92 and primary phases (Ryu et al., 2016). Also some experimental studies indicate small but

93 significant isotope fractionation during preferential incorporation of light $\mathrm{Mg}$ isotopes into

94 secondary minerals, such as chrysotile, brucite, saponite and stevensite (Wimpenny et al., 2010;

95 Li et al., 2014; Hindshaw et al., 2020). In contrast, other phases, such as brucite, kerolite and

96 lizardite have shown preferential incorporation of heavy Mg isotopes (Wimpenny et al., 2014;

97 Ryu et al., 2016). Likewise, field studies have reported both enrichment in light and heavy $\mathrm{Mg}$

98 isotopes in soil minerals. Some studies suggest that secondary minerals have heavy $\mathrm{Mg}$ isotope

99 compositions due to either the preferential incorporation of heavy Mg isotopes into mineral

100 lattice, or the adsorption of heavy Mg isotopes onto mineral surface/interlayer (Tipper et al.,

101 2006; Teng et al., 2010; Huang et al., 2012; Opefergelt et al., 2012; Liu et al., 2014; Gao et al.,

102 2018), but the opposite was also shown (Pogge von Strandmann et al., 2008). An experimental

103 study by Hindshaw et al. (2020) suggests that the direction of Mg isotope fractionation depends

104 on the difference in the $\mathrm{Mg}-\mathrm{O}$ bond length between a crystal lattice and solution. Although the

105 number of experimental studies has increased, few investigations have focused on natural

106 weathering profiles drawn from clear geological and ecological contexts. As a consequence, we 107 lack clarity on $\mathrm{Mg}$ isotope fractionation during key soil forming processes.

108 Here, we examine processes responsible for $\mathrm{Mg}$ isotope fractionation in basaltic soils

109 collected along a well-known humid-environment chronosequence in the Hawaiian Islands (e.g.

110 Vitousek et al. 1997; Vitousek, 2004; Chadwick et al., 1999, 2009; Chorover et al., 2004;

111 Wiegand et al., 2005; Ziegler et al., 2005; Pett-Ridge et al., 2007). This chronosequence allows

112 us to better understand the fate of $\mathrm{Mg}$ and its isotopes from the initial stages of basalt leaching to

113 the slow accumulation of metastable secondary minerals and their eventual reorganization into 114 relatively inert secondary crystalline phases (secondary mineral formation). We also assess the 
115 role of atmospheric deposition and vegetation assimilation and release of $\mathrm{Mg}$. This study

116 provides new insights into understanding the behavior of Mg isotopes during basalt weathering

117 and secondary mineral transformation as a function of age as well as the biogeochemical cycle of

$118 \mathrm{Mg}$ closely related to the long-term $\mathrm{CO}_{2}$ cycle.

120 2. MATERIALS AND METHODS

121 2.1. Study area

122 Detailed descriptions of the study area are given in previous studies (Crews et al., 1995;

123 Vitousek et al., 1997; Vitousek, 2004; Ryu et al., 2014). In short, the Hawaiian chronosequence

124 considered here varies in age from $0.3 \mathrm{ka}$ to $4100 \mathrm{ka}$ and has been referred to as the "Long-

125 Substrate Age Gradient (LSAG)" (Vitousek et al., 1997). All six sites where the profiles have

126 developed in lava mixed with tephra with subsrate ages of $0.3,20,150,1400$, and $4100 \mathrm{ka}$ are

127 near $1200 \mathrm{~m}$ elevation, receive $2500 \mathrm{~mm}$ annual rainfall, and have a mean annual temperature of

$12815^{\circ} \mathrm{C}$. The soils and climate support rain forests composed of primarily of Metrosideros

129 polymorpha and Cibotium spp (Vitousek, 2004). The two youngest sites (0.3 ka; Thurston (Th)

130 and Ola'a $(\mathrm{Ol}))$ are in Keanakakoi tephra derived from phreatomagmatic eruptions of tholeiitic

131 composition at the summit of Kilauea (McPhie et al., 1990; Fiske et al., 2009), while the older

132 sites ( $\geq 20 \mathrm{ka})$ are composed of alkali basalt, such as hawaiite, mugearite, and their associated

133 tephra (MacDonald et al., 1983; Wright and Heltz, 1986; Wolfe and Morris, 1996). All soils are

134 located on primary shield volcano surfaces, where physical erosion and groundwater influences

135 are minimal. Although the two youngest soils are Andisols dominated by primary basaltic

136 material (glass, plagioclase, augite, olivine, magnetite, and ilmenite), primary volcanic minerals

137 and volcanic glass are absent and are replaced by non-crystalline secondary minerals in soils 20 
138 ka and older (Kurtz et al., 2001). The two intermediate-age soils, $20 \mathrm{ka}$ and $150 \mathrm{ka}$, are highly

139 weathered Andisols composed of chemically active metastable secondary minerals such as

140 ferrihydrite, allophane, and immogolite. The two oldest sites, $1400 \mathrm{ka}$ and $4100 \mathrm{ka}$, are highly

141 weathered Ultisols and Oxisols dominated by relatively inert crystalline $\mathrm{Al}$ - and Fe-oxides and

142 kaolin minerals (Chadwick et al., 1999; Vitousek et al., 1997; Pett-Ridge et al., 2007).

143 Furthermore, although quartz and mica in Hawaiian soils are derived uniquely from continental

144 dust sources (Kurtz et al., 2001), only small amounts of mica may be found in the older soil

145 profiles (Ziegler et al., 2005) because dust undergoes chemical weathering in the soil

146 environment older than $150 \mathrm{ka}$, with mica weathering faster than quartz (Kurtz et al., 2001).

148 2.2. Sampling and sequential leaching

149 Soils studied here are the same as those investigated in a companion Li isotope study

150 (Ryu et al., 2014). Samples were collected from hand-dug pits to about $1 \mathrm{~m}$ depth except for the

151 youngest soil; Thurston (Th) is about $40 \mathrm{~cm}$ deep and overlies unweathered pahoehoe lava, and

152 Ola'a $(\mathrm{Ol})$ is about $70 \mathrm{~cm}$ deep and overlies a buried soil on the $\sim 1$ ka old Kulanaokuaiki tephra

153 (Fiske et al., 2009; Fig. S1).

154 In order to distinguish the $\mathrm{Mg}$ isotopic composition of different $\mathrm{Mg}$ fractions (i.e., labile

155 versus residual $\mathrm{Mg}$ ) in the soil samples and two USGS reference materials (BHVO-2 and BIR-

156 1), we conducted a three-step leaching and digestion; (1) MilliQ water leach (water leachate), (2)

$1571 \mathrm{M}$ ammonium chloride $\left(\mathrm{NH}_{4} \mathrm{Cl}\right)$ leach $\left(\mathrm{NH}_{4} \mathrm{Cl}\right.$ leachate), (3) $4 \mathrm{M}$ acetic acid (HAc) leach (HAc

158 leachate), and (4) complete digestion of the silicate residue (residue).

159 Steps (1) to (3) define the "labile" Mg, which means the Mg released or exchanged

160 relatively easily when the soil sample is in contact with soil solution. It includes the $\mathrm{Mg}$ from the 
161 macroporosity (water leachate), the ion-exchangeable $\mathrm{Mg}\left(\mathrm{NH}_{4} \mathrm{Cl}\right.$ leachate), and the less

162 leachable Mg in carbonates and/or Fe-oxyhydroxides/silicate lattice (HAc leachate; Jacobson and

163 Blum, 2000; Chan and Hein, 2007; Wimpenny et al., 2014).

164 Step (4) defines the "residual" Mg, which means the Mg mainly associated with the

165 silicate minerals but also (nano)crystalline $\mathrm{Fe}-$ and Al-phases.

166

$167 \quad 2.3$ Sample preparation and elemental analysis

168 About $1.0 \mathrm{~g}$ of the soil samples was reacted with $10 \mathrm{~mL}$ of MilliQ water for $6 \mathrm{~h}$ using a

169 Thermo Scientific Vari-Mix ${ }^{\mathrm{TM}}$ Test Tube Rocker. The mixture was centrifuged, and the

170 supernatant was passed through a $0.45 \mu \mathrm{m}$ polypropylene syringe filter, dried, and re-dissolved

171 in $5 \% \mathrm{HNO}_{3}$. The residue was then reacted with $10 \mathrm{~mL}$ of $1 \mathrm{M} \mathrm{NH}_{4} \mathrm{Cl}$ for $6 \mathrm{~h}(\mathrm{pH}=7)$ prior to

172 repeating the same procedures above. Thereafter, the residue was reacted with $10 \mathrm{~mL}$ of $4 \mathrm{M}$

173 HAc for $6 \mathrm{~h}(\mathrm{pH}=2)$ and repeated the same procedures above. Finally, the residue was dried and

174 a $0.1 \mathrm{~g}$ sub-sample was powdered and completely digested in a 5:3 mixture of $\mathrm{HF}$ and $\mathrm{HNO}_{3}$.

175 Bulk soil samples crushed in a shatter box equipped with a tungsten carbide grinding container

176 were also completely digested in a 5:3 mixture of $\mathrm{HF}$ and $\mathrm{HNO}_{3}$. All HF-digested samples were

177 dried, refluxed several times in $6.0 \mathrm{M} \mathrm{HCl}$ to remove fluorides, and re-dissolved in $5 \% \mathrm{HNO}_{3}$.

178 Cation and trace element concentrations were measured using a Perkin Elmer Optima 8300 ICP-

179 AES and a Thermo Elemental X-7 ICP-MS, respectively at the Korea Basic Science Institute

180 (KBSI). Repeated analyses of USGS rock standard powders (BCR-2, BHVO-2, and BIR-1)

181 yielded external reproducibilities better than $\pm 5 \%$.

182

183

2.4. Magnesium isotope analysis 
Magnesium was separated from matrix elements using an AG-50W-X8 resin (200-400

185

186

187

188

189

190

191

192

193

194

195

196

197

198

199

200

201

202

203

204

205

mesh). After loading the sample, matrix elements were eluted with $5 \mathrm{~mL}$ of $0.15 \mathrm{M} \mathrm{HF}$, followed by $10 \mathrm{~mL}$ of the mixture of $0.5 \mathrm{M} \mathrm{HCl}$ and $95 \%$ acetone, and $8 \mathrm{~mL}$ of $1 \mathrm{M} \mathrm{HNO}_{3}$ before collecting $\mathrm{Mg}$ in $12 \mathrm{~mL}$ of $1 \mathrm{M} \mathrm{HNO}_{3}$. Magnesium isotope ratios were measured using a Neptune MC-ICP-MS upgraded with a large dry interface pump at the KBSI. Samples were introduced using a quartz dual cyclonic spray chamber and analyzed with a standard-samplestandard bracketing method. Sample intensities were matched to within $10 \%$ of the intensity of the standard. Using the Jet sample cone and X-skimmer cone, the sensitivity was $\sim 100 \mathrm{~V} / \mathrm{ppm}$ on mass 24 at a typical uptake rate of $100 \mu \mathrm{L} / \mathrm{min}$. Prior to isotopic analysis, each sample was checked for yield and the concentration of matrix elements (Al, $\mathrm{Ca}, \mathrm{Fe}, \mathrm{K}, \mathrm{Mn}, \mathrm{Na}$, and Ti). Yields were about $100 \%$ and the matrix concentration did not exceed $1 \%$ of the $\mathrm{Mg}$ concentrations. The total procedural blanks were negligible with less than $3 \mathrm{ng}$ of $\mathrm{Mg}$. All ${ }^{26} \mathrm{Mg} /{ }^{24} \mathrm{Mg}$ and ${ }^{25} \mathrm{Mg} /{ }^{24} \mathrm{Mg}$ ratios are reported in delta notation relative to DSM-3, where $\delta^{\mathrm{x}} \mathrm{Mg}=$ $\left[\left({ }^{\mathrm{x}} \mathrm{Mg} /{ }^{24} \mathrm{Mg}\right)_{\text {sample }} /\left({ }^{\mathrm{x}} \mathrm{Mg} /{ }^{24} \mathrm{Mg}\right)_{\mathrm{DSM}-3}-1\right] \times 1000$ and $x=25$ or 26 . Samples were analyzed in replicate $(n=3-4)$, where uncertainties are reported as two standard deviations $(2 \sigma)$. The longterm $\mathrm{Mg}$ isotope measurements of three reference materials (DSM-3, CAM-1, and SRM980) yielded $\delta^{26} \mathrm{Mg}$ values of $-0.01 \pm 0.06 \%$ o $(2 \sigma, \mathrm{n}=408),-2.62 \pm 0.06 \%$ o $(2 \sigma, \mathrm{n}=404)$, and $-4.32 \pm$ 0.09\%o $(2 \sigma, \mathrm{n}=249)$, respectively, in good agreement with reported values (Table S1; e.g., Galy et al., 2001, 2003; Tipper et al., 2008b; Huang et al., 2009; Lee et al., 2014). The chemical purification, and the precision and accuracy of $\mathrm{Mg}$ isotope measurements have been validated using the USGS powder and IAPSO seawater reference materials. BHVO-2 yielded a $\delta^{26} \mathrm{Mg}$ value of $-0.20 \pm 0.07 \%$ o $(2 \sigma, \mathrm{n}=3), \mathrm{BIR}-1$ yielded a $\delta^{26} \mathrm{Mg}$ value of $-0.17 \pm 0.08 \%$ o $(2 \sigma, \mathrm{n}=4)$ 
and IAPSO yielded a $\delta^{26} \mathrm{Mg}$ value of $-0.83 \pm 0.04 \%$ o $(2 \sigma, \mathrm{n}=36)$, consistent with reported values

207 (Table S1; Teng, 2017 and references therein).

208

209

2.5. Calculations of Mg gain or loss

210

The relative gain $\left(\tau_{j, w}>0\right)$ or loss $\left(\tau_{j, w}<0\right)$ of $\mathrm{Mg}$ with depth at each weathering profile

211 was estimated as follows (Brimhall and Dietrich, 1987; Chadwick et al., 1990):

$212 \tau_{j, w}=\frac{C_{j, w} \times C_{i, p}}{C_{j, p} \times C_{i, w}}-1$,

213 where $C$ is the concentration of an element, $w$ and $p$ refer to the weathered and parent materials,

214 respectively, and $i$ and $j$ refer to the immobile and mobile elements, respectively. Kurtz et al.

215 (2000) performed comprehensive analyses of a wide range of trace metals in Hawaiian soils and

216 found that that $\mathrm{Nb}$ and $\mathrm{Ta}$ are the least mobile elements in these soils compared to traditionally

217 known immobile elements, such as $\mathrm{Th}, \mathrm{Zr}$ and $\mathrm{Al}$. Thus, for these calculations, we used $\mathrm{Nb}$ as

218 the index element.

219 The depth-integrated $\tau_{M g}$ allows us to calculate the total loss or gain of $\mathrm{Mg}$ and other

220 elements over the timescale of each profile as follows:

$221 \tau_{\text {int }}=\frac{\sum\left(\tau_{h} \cdot \rho_{h} \cdot z_{h}\right)}{\sum\left(\rho_{h} \cdot z_{h}\right)}$,

222 where $\tau_{h}$ is the $\tau_{j, w}$ value of each horizon ( $h$; Eq. (1)), $z_{h}$ is horizon thickness, and $\rho_{h}$ is horizon

223 density taken from Pett-Ridge et al. (2007).

224

225

\subsection{Quantifying relative contribution of each $\mathrm{Mg}$ source}


Previous work has shown that with age basalt weathering becomes relatively less

227 important to the soil budget and atmospheric inputs become more important, in particular for $\mathrm{Sr}$

228 and $\mathrm{Nd}$ (Vitousek et al., 1997; Kurtz et al., 2001; Chadwick et al., 2009). However, a recent

229 study also showed that atmospheric input is not a primary control of Li isotopic compositions in

230 the Hawaiian soils (Ryu et al., 2014). It is possible to estimate the relative contribution from the

231 various $\mathrm{Mg}$ sources for each studied soil profile, as has been done for $\mathrm{U}$ and Li (Pett-Ridge et al.,

232 2007; Ryu et al., 2014). The Mg contribution from Asian dust can be estimated because the

233 elemental composition of the dust in Hawaii has remained relatively invariant during the past

2344100 ka (Kyte et al., 1993). Thus,

$235 \quad M g_{\text {dust }}=C_{\text {dust }}^{M g} \cdot F_{\text {dust }} \cdot t$,

236 where $C_{\text {dust }}^{M g}$ is the average $\mathrm{Mg}$ concentration in either upper continental crust $(\mathrm{UCC} ; \mathrm{Mg}]=1.5$

237 wt.\%; Rudnick and Gao, 2014) or in loess $\left([\mathrm{Mg}]=0.58 \mathrm{wt} \%\right.$; Li et al., 2010), $F_{d u s t}$ is the average

238 long-term dust deposition rate for Hawaii $\left(30 \mathrm{mg} / \mathrm{cm}^{2} / \mathrm{ka}\right.$ for the younger soils $(<20 \mathrm{ka})$ and 125

$239 \mathrm{mg} / \mathrm{cm}^{2} / \mathrm{ka}$ for the older soils ( $\left.\geq 20 \mathrm{ka}\right)$; Kurtz et al., 2001), and $t$ is the age of the soil site.

240 Similarly, the atmospheric Mg input linked to rainwater can be calculated as follows:

$241 \quad M g_{\text {rainwater }}=C_{\text {rainwater }}^{M g} \cdot M A P \cdot t$,

242 where $C_{\text {rainwater }}^{\mathrm{Mg}}$ is the $\mathrm{Mg}$ concentration in Hawaiian rain $\left(5.83 \times 10^{-2} \mu \mathrm{g} / \mathrm{cm}^{3}\right.$ at Thurston (Hawai'i)

243 and $1.43 \times 10^{-1} \mu \mathrm{g} / \mathrm{cm}^{3}$ at Kokee (Kauai); Carrillo et al., 2002) and MAP is the Mean Annual

244 Precipitation (2500 mm/yr). Since the sites exhibit minimal physical erosion, the overall

245 weathering thickness should be directly linked to their age (e.g., Pett-Ridge et al., 2007). In this

246 context, the quantity of $\mathrm{Mg}$ released from the parent basalt can be estimated as follows:

$247 \quad \mathrm{Mg}_{\text {basalt }}=C_{\text {basalt }}^{\mathrm{Mg}} \cdot z_{t} \cdot S_{c} \cdot \rho_{\text {basalt }}$, 
248 where $C_{\text {basalt }}^{M g}$ is the $\mathrm{Mg}$ concentration in basalt $(6.1 \mathrm{wt} . \%$ in tholeiitic basalt for the two youngest

249 sites, and 3.3, 2.2, 6.1 and $4.9 \mathrm{wt} . \%$ in alkali basalt for the older sites, respectively; Ziegler et al.,

$2502005), z_{t}$ is the total regolith thickness $(\mathrm{m}), \rho_{\text {basalt }}$ is the average density of basalt including void

251 and infilled vesiculated tephra $\left(1.25 \mathrm{~g} / \mathrm{cm}^{3}\right.$; Chadwick et al., 2003), and $S_{c}$ is the collapse factor.

252 Total regolith thickness is difficult to determine even in cases where a backhoe or drill is

253 available because of local variability related to void spaces and hydrological permeability

254 (Goodfellow et al., 2013). We calculated values representing soil horizons to 1-m depth.

255 Eqs. (3) - (5) allow us to calculate the total $\mathrm{Mg}$ in the regolith, which is the sum of $\mathrm{Mg}$

256 released from the parent basalt, with $\mathrm{Mg}$ added from dust and rainwater along the course of the

257 regolith development as follows:

$258 M g_{\text {total }}=M g_{\text {basalt }}+M g_{\text {dust }}+M g_{\text {rainwater }}$,

259 It is possible to compare $M g_{\text {total }}$ corresponding to the regolith residence time, to the $\mathrm{Mg}$

260 currently present in the regolith, $M g_{\text {present }}$ (i.e. depth-integrated $\mathrm{Mg}$ mass per unit area). The

261 difference between these two parameters allows the total $\mathrm{Mg}$ exported by the profile $M g_{\text {loss }}$ to be

262 evaluated as follows:

$263 \quad M g_{\text {present }}=\sum_{h}\left(\rho_{h} \cdot z_{h} \cdot C_{h}^{M g}\right)$

264

$M g_{\text {loss }}(\%)=\left[M g_{\text {present }} /\left(M g_{\text {basalt }}+M g_{\text {dust }}+M g_{\text {rainwater }}\right)-1\right] \times 100$,

265 where $C_{h}^{M g}$ is the Mg concentration in the each soil horizon. All results are given in Table S3.

\section{3. RESULTS}



in Ryu et al. (2014). Magnesium concentrations ([Mg]) of the bulk soil are variable with depth

271 and age, ranging from 0.07 to 8.79 wt.\% (Fig. 1). At the $0.3 \mathrm{ka}$ sites (Th and $\mathrm{Ol}$ ), $[\mathrm{Mg}]$ in the organic-rich surface horizons is 0.52 and $1.08 \mathrm{wt} . \%$, respectively, and abruptly increases to about $6.2 \mathrm{wt} . \%$ for the deeper horizons, similar to tholeiitic basalt (6.1 wt.\%; Ziegler et al., 2005). At the $20 \mathrm{ka}$ site, $[\mathrm{Mg}]$ is relatively low for the upper horizons $(0.14 \mathrm{wt} \%$ on average; $0-27 \mathrm{~cm})$ and gradually increases to $1.66 \mathrm{wt} \%$ in the deeper horizons $(1.66 \mathrm{wt} . \%$; $94-110 \mathrm{~cm})$, which is

276 much lower than that of alkali basalt (2.3 wt.\%; Chadwick et al., 2003). At the three oldest sites

$277(150,1400$, and $4100 \mathrm{ka}),[\mathrm{Mg}]$ is quite low, ranging from 0.07 to $0.71 \mathrm{wt} . \%$, with an average of $0.25 \pm 0.33$ wt. $\%(2 \sigma, n=36)$. $(-0.16 \pm 0.36 \%, 2 \sigma, \mathrm{n}=36$; Table 1 and Fig. 2$)$. The youngest sites $(0.3 \mathrm{ka}$; Th and $\mathrm{Ol})$ exhibit

281 little variation in $\delta^{26} \mathrm{Mg}(-0.27 \pm 0.09 \%$, $2 \sigma, \mathrm{n}=13)$, in good agreement with reported $\delta^{26} \mathrm{Mg}$ for 282 the Hawaiian basalts $(-0.26 \pm 0.06 \%, 2 \sigma, \mathrm{n}=11$; Zhong et al., 2017) and for fresh oceanic basalts 283 more generally $\left(-0.26 \pm 0.07 \%, 2 \sigma, \mathrm{n}=110\right.$; Teng et al., 2010). At the $20 \mathrm{ka}$ site, $\delta^{26} \mathrm{Mg}$ values 284 range from $-0.44 \%$ for the organic-rich surface sample to $-0.15 \%$ for the subsurface samples 285 with an average of $-0.26 \pm 0.26 \%$ o $(2 \sigma, \mathrm{n}=4)$. At the $150 \mathrm{ka}$ site, $\delta^{26} \mathrm{Mg}$ values range from $-0.60 \%$ o 286 for the organic-rich surface sample to $-0.01 \%$ for the subsurface samples with an average of $287-0.12 \pm 0.47 \%$ o $(2 \sigma, \mathrm{n}=6)$. At the $1400 \mathrm{ka}$ site, $\delta^{26} \mathrm{Mg}$ value is the lowest at the organic-rich 288 surface $(-0.55 \%)$, and increases up to $0.26 \%$ for the subsurface samples with an average of $289-0.04 \pm 0.54 \%$ o $(2 \sigma, \mathrm{n}=6)$. At the oldest site $(4100 \mathrm{ka}), \delta^{26} \mathrm{Mg}$ values are relatively consistent, 290 ranging from -0.11 to $+0.05 \%$, with an average $-0.05 \pm 0.13 \%$ o $(2 \sigma, n=6)$, regardless of depth. 291 
3.2. Mg isotope compositions in sequential leachates and residue

In the various leachates, $\mathrm{Mg}$ displays a wide range of $\delta^{26} \mathrm{Mg}$ values, from -1.01 to

$294+0.06 \%$ o $(-0.37 \pm 0.53 \%, 2 \sigma, \mathrm{n}=58$; Table 2 and Fig. 2$)$. The water and $\mathrm{NH}_{4} \mathrm{Cl}$ leachates have 295 similar $\delta^{26} \mathrm{Mg}$ values, within uncertainty, of $-0.37 \pm 0.53 \%$ o $(2 \sigma, \mathrm{n}=23)$ and $-0.28 \pm 0.49 \%$ o $(2 \sigma$, $296 \mathrm{n}=14)$, respectively, The HAc leachate displays relatively lighter $\delta^{26} \mathrm{Mg}$ values of $-0.42 \pm 0.53 \%$ o $297(2 \sigma, \mathrm{n}=21)$. The residual $\mathrm{Mg}$, With the exception of the organic-rich surface samples, residual $298 \mathrm{Mg}$ at the sites older than $20 \mathrm{ka}$, showed much heavier $\delta^{26} \mathrm{Mg}$ values of $+0.02 \pm 0.48 \%$ o $(2 \sigma, \mathrm{n}=25)$ 299 (Table 2). We define a "labile" pool as the sum of $\mathrm{Mg}$ released during the water, $\mathrm{NH}_{4} \mathrm{Cl}$ and $\mathrm{HAc}$ 300 leaches, which shows that the two youngest sites $(0.3 \mathrm{ka}$; Th and $\mathrm{Ol})$, display a labile $\mathrm{Mg}$ with an 301 average $\delta^{26} \mathrm{Mg}$ value of $-0.18 \pm 0.13 \%$ o, $(2 \sigma, \mathrm{n}=31)$. The residues ('residual' $\mathrm{Mg}$ ) show an average $302 \delta^{26} \mathrm{Mg}$ value of $-0.23 \pm 0.05 \%$ o $(2 \sigma, \mathrm{n}=11)$ that is consistent with Hawaiian basalt within 303 uncertainties.

304 In contrast, at the $20 \mathrm{ka}$ site, the 'labile' $\mathrm{Mg}$ in the organic-rich surface sample becomes 305 depleted in heavy $\mathrm{Mg}$ isotopes $(-0.49 \pm 0.23 \%$, $2 \sigma, \mathrm{n}=3)$ compared to the residual $\mathrm{Mg}(-0.07 \%$, $306 \mathrm{n}=1$ ). In the subsurface samples of the same site, both labile and residual $\mathrm{Mg}$ display similar

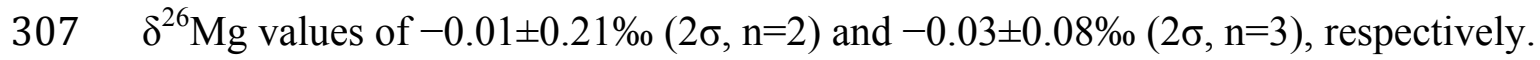
Interestingly, at the sites older than $20 \mathrm{ka}$, the labile $\mathrm{Mg}$ from the organic-rich surface 309 samples display much lighter $\delta^{26} \mathrm{Mg}$ values $(-0.59 \pm 0.31 \%$, $2 \sigma, \mathrm{n}=15)$ compared to basalts. For

310 the subsurface samples at the sites older than $150 \mathrm{ka}$, the residual $\mathrm{Mg}$ becomes enriched in heavy

$311 \mathrm{Mg}$ isotopes $(+0.24 \pm 0.24 \% \mathrm{o}, 2 \sigma, \mathrm{n}=13)$ compared to the labile $\mathrm{Mg}(-0.59 \pm 0.31 \% \mathrm{o}, 2 \sigma, \mathrm{n}=15)$.

\section{4. DISCUSSION}


Figure 1 shows the depth variations of $[\mathrm{Mg}]$ in all soil profiles. In the organic-rich surface

316 horizons, $\tau_{M g}$ decreases from $-18 \%$ to $-99 \%$ with age, indicating progressive loss of $\mathrm{Mg}$ during

317 pedogenesis. In the two youngest soils, the organic-rich surface is already depleted by up to $29 \%$

318 in Mg compared to parent basalt. This could be partly explained by the dilution by soil organic

319 matter (SOM) due to the high SOM content of the $0-3 \mathrm{~cm}$ depth sample (56 wt.\%) (Ziegler et al.,

320 2005). Another possibility is that $\mathrm{Mg}$ released from basalt leaching and/or from decomposition of

321 plant would move deeper into the profile or be lost because $\mathrm{Mg}$ is highly mobile and water-

322 soluble. Below $12 \mathrm{~cm}$ depth in the two youngest soils $(0.3 \mathrm{ka}), \tau_{M g}$ turns into positive, indicating

323 the enrichment relative to the surface and the relative gain of $\mathrm{Mg}$ compared to basalt. This

324 feature is likely the result of the surface $\mathrm{Mg}$ moving deeper into the profile. At the sites older

325 than $0.3 \mathrm{ka}, \tau_{M g}$ abruptly decreased near $-100 \%$ compared to the $0.3 \mathrm{ka}$ sites due to the

326 significant consumption of primary minerals by $20 \mathrm{ka}$ (Vitousek et al., 1997). In contrast, both

$327[\mathrm{Al}]$ and $[\mathrm{Fe}]$ increase with depth as well as age (Fig. 1) due to residual enrichment and

328 redistributions. These metals are more strongly retained during progressive mineral

329 transformations starting with the synthesis of metastable SRO minerals and followed by their

330 transformation into relatively inert secondary minerals. Although SRO minerals (e.g., allophane,

331 imogolite and ferrihydrite) and sesquioxides (hematite and goethite) replaced primary minerals

332 during the first $20 \mathrm{ka}$ (Chorover et al., 1999) with large specific surface areas of $600 \mathrm{~m}^{2} / \mathrm{g}$ (Hall

333 et al., 1985) and $120 \mathrm{~m}^{2} / \mathrm{g}$ (Schwertmann and Taylor, 1989), respectively, only a little Mg was

334 trapped within aggregates formed by association of SRO and organic matter (Opfergelt et al.,

335 2014). At the three older sites $(150,1400$ and $4100 \mathrm{ka}), \tau_{M g}$ is close to $-100 \%$ at all depths

336 although the contents of poorly crystalline total (gibbsite and poorly crystalline kaolin minerals) 
337 and kaolin minerals (kaolinite and halloysite) significantly increase (Ziegler et al., 2005).

338 Overall, most of $\mathrm{Mg}$ released from basalt leaching was lost (up to 100\%) in the soils older than

$3390.3 \mathrm{ka}$ and only a small amount of the remaining $\mathrm{Mg}$ was either trapped within aggregates

340 formed by association of secondary phases and organic matter (Opfergelt et al., 2014) or

341 incorporated into the octahedral sites of secondary phases.

342 Depth-integrated $\tau_{M g}\left(\tau_{\text {int }}^{M g}\right)$ values allow us to investigate the variations of Mg along the

343 LSAG (Fig. 3). As previously described in Ryu et al. (2014), $\tau_{\text {int }}$ for alkali elements (Na and K)

344 are negative at all sites and the older soils ( $\geq 20 \mathrm{ka}$ ) display average $\tau_{\text {int }}$ of close to $-100 \%$,

345 indicating that both $\mathrm{Na}$ and $\mathrm{K}$ are completely lost after $20 \mathrm{ka}$ (Vitousek et al., 1997). In contrast,

$346 \tau_{\text {int }}$ for alkaline earth elements ( $\mathrm{Sr}$ and $\mathrm{Mg}$ ) are positive at the two youngest sites $(0.3 \mathrm{ka})$.

347 Interestingly, at the $20 \mathrm{ka}$ site $\tau_{\text {int }}^{\mathrm{Mg}}$ is relatively high compared to $\mathrm{Na}, \mathrm{K}$, and $\mathrm{Sr}$, similar to $\tau_{\text {int }}^{L i}$

348 (Ryu et al., 2014). This relatively high $\tau_{\text {int }}^{M g}$ relative to $\mathrm{Na}, \mathrm{K}$ and $\mathrm{Sr}$ at the $20 \mathrm{ka}$ could be due to

349 the fact that the surface $25 \mathrm{~cm}$ was deposited by renewed eruptions about $5 \mathrm{ka}$ at the $20 \mathrm{ka}$ site

350 (Chadwick et al., 2009) and/or to the lower mobility of Mg (compared to alkali elements) during

351 mineral leaching. For the older sites ( $\geq 150 \mathrm{ka}$ ), $\tau_{\text {int }}^{\mathrm{Mg}}$ is close to $-100 \%$, indicating that secondary

352 phases do not retain $\mathrm{Mg}$ during neoformation, in contrast to Li which was significantly retained

353 by crystalline phases (e.g., kaolin minerals; Ryu et al., 2014). Previous studies showed that

354 gibbsite and kaolinite contain small amount of Mg (typically $<\sim 0.02$ wt.\%) (Peskleway et al.,

355 2003; Mermut and Cano, 2001).

$356 \quad$ Previous works have shown that with age basalt leaching becomes relatively less

357 important to the soil budget for several elements, such as $\mathrm{Sr}$ and $\mathrm{Si}$, and atmospheric inputs (dust

358 and rainwater) become more important (Kurtz et al., 2001; Ziegler et al., 2005; Chadwick et al., 
2009). However, a recent $\mathrm{Li}$ isotope study showed that the relative proportion of each Li source

360 (basalt, dust and precipitation) is $80-100 \%, 6-20 \%$, and $0.8 \%$, respectively (Ryu et al., 2014),

361 indicating a major contribution of basalt weathering to the Li budget that is significantly retained 362 in secondary phases, in particular in kaolin minerals (kaolinite and halloysite). Using Eqs. (3) -

363 (8) above, we calculated the contribution of each $\mathrm{Mg}$ source to the soil $\mathrm{Mg}$ budget and $\mathrm{Mg}$ loss

364 (Fig. S2 and Table S3). The results show that the parent basalt provided between $78 \%$ and $100 \%$

$365 \mathrm{of}_{\mathrm{total}}$ and dust becomes significant from $150 \mathrm{ka}(6 \%)$ and reached at maximum $22 \%$ of

$366 \mathrm{Mg}_{\text {total }}$ at $4100 \mathrm{ka}$. It is interesting to note that although the impact of dust input on the Sr budget

367 is significant at $150 \mathrm{ka}$ (Stewart et al., 2001), it is not the case in the Mg budget because dust is

368 highly depleted in Mg compared to basalt (Kurtz et al., 2001), and because most of Mg at the

369 older sites ( $\geq 20 \mathrm{ka}$ ) are lost due to weathering, dissolution and leaching by soil waters (Table

370 S3).

371

372

\subsection{Magnesium isotopic compositions of 'labile’ $\mathrm{Mg}$}

373 A sequential leaching of USGS reference materials (BHVO-2 and BIR-1) showed that

374 water leachate yielded lighter $\delta^{26} \mathrm{Mg}$ values compared to the other leachates, indicating water-

375 soluble $\mathrm{Mg}$ is depleted in heavy $\mathrm{Mg}$ isotopes (Table $\mathrm{S} 1$ ). However, as shown in section 3.2,

376 Hawaiian soil samples showed that the water and $\mathrm{NH}_{4} \mathrm{Cl}$ leachates have similar $\delta^{26} \mathrm{Mg}$ values, of

377 which the $0.3 \mathrm{ka}$ site samples have $\delta^{26} \mathrm{Mg}$ values of $-0.20 \pm 0.11 \%$ o $(2 \sigma, \mathrm{n}=9)$ and $-0.11 \pm 0.11 \%$ o

$378(2 \sigma, \mathrm{n}=7)$, respectively. Although it is difficult to compare them to soil samples older than $20 \mathrm{ka}$

379 due to a limited data, both leachates also show similar $\delta^{26} \mathrm{Mg}$ values within uncertainties (Table

380 2). This result is consistent with previous work showing that water and exchangeable fractions

381 have similar isotopic compositions for $\mathrm{Ca}, \mathrm{Sr}$, and $\mathrm{Ba}$ isotope systems (Bullen and Chadwick, 
2016). Thus, the water and $\mathrm{NH}_{4} \mathrm{Cl}$ leachates together are hereafter referred to 'exchangeable

$383 \mathrm{Mg}$ '. Previous studies have shown that exchangeable Mg in volcanic soils (Opfergelt et al.,

384 2014), clay minerals (Wimpenny et al., 2014) and paddy soils (Gao et al., 2018) leached by

385 either $\mathrm{NH}_{4} \mathrm{Ac}$ or $\mathrm{NH}_{4} \mathrm{Cl}$ are depleted in heavy $\mathrm{Mg}$ isotopes compared to bulk samples, suggesting

386 that the isotopic composition of exchangeable $\mathrm{Mg}$ is likely to reflect either the fluid phases in

387 which the sample last equilibrated (Wimpenny et al., 2014; Gao et al., 2018) or the mixture of

388 different $\mathrm{Mg}$ sources (sea spray and organic matter) as well as the possible effects of sorption

389 (Opfergelt et al., 2014). However, exchangeable $\mathrm{Mg}$ in the Hawaiian soil samples are enriched in

390 either heavy $\mathrm{Mg}$ isotopes at the $0.3 \mathrm{ka}$ sites or depleted at the sites older than $20 \mathrm{ka}$. We will

391 discuss the processes controlling the isotopic composition of exchangeable $\mathrm{Mg}$ in a later section.

392 The HAc leachates have Mg isotopic composition either similar to or a bit more depleted

393 in heavy $\mathrm{Mg}$ isotopes compared to exchangeable $\mathrm{Mg}$, of which the $0.3 \mathrm{ka}$ site samples have

$394 \delta^{26} \mathrm{Mg}$ value of $-0.18 \pm 0.09 \%$ o $(2 \sigma, \mathrm{n}=9)$ and the samples at the older sites $(\geq 20 \mathrm{ka})$ have $\delta^{26} \mathrm{Mg}$

395 value of $-0.67 \pm 0.35 \%(2 \sigma, n=9)$. However, a previous study found that the HAc leachates from

396 clay minerals were relatively enriched in heavy Mg isotopes (Wimpenny et al., 2014), suggesting

397 that while the HAc leach mostly accounts for either ion-exchangeable $\mathrm{Mg}$, it may also remove

398 other easily leachable phases (carbonates or Fe-oxyhydroxides; Jacobson and Blum, 2000; Chan

399 and Hein, 2007) or cause some breakdown of the mineral lattice (Jacobson and Blum, 2000).

400 Because the Hawaiian soils we sampled contain no pedogenic carbonates (Vitousek et al., 1997;

401 Chadwick et al., 2009; Ziegler et al., 2005), the Mg isotopic composition of the HAc leachates

402 would reflect less labile, more strongly bound Mg onto either surface complexes of secondary

403 phase (SRO) and soil organic matter (SOM) and/or Fe-oxyhydroxides. We will discuss the

404 processes controlling the isotopic composition of $\mathrm{Mg}$ from HAc leachates in a later section. 


\subsubsection{Behavior of Mg isotopes in the organic-rich surface soil}

Although simple mass balance indicates that the contribution of basalt weathering to the soil $\mathrm{Mg}$ budget is dominant, the contribution of other sources, such as dust, rainwater and plants, on $\mathrm{Mg}$ isotopic compositions in the surface samples (O horizon; $<6 \mathrm{~cm}$ except for $20 \mathrm{ka}$ site)

410 could be significant because $[\mathrm{Mg}]$ is quite depleted (Fig. 1). Figure 4a shows $\mathrm{Mg}$ isotope

411 variations in the organic-rich surface soil as a function of age. The $\delta^{26} \mathrm{Mg}$ values of 'labile' $\mathrm{Mg}$

412 (released by water, $\mathrm{NH}_{4} \mathrm{Cl}$ and $\mathrm{HAc}$ leach, as explained in section 2.2) in the surface samples 413 range from $-0.88 \pm 0.24 \%$ o $(2 \sigma, \mathrm{n}=3)$ at the $150 \mathrm{ka}$ site to $-0.23 \pm 0.13 \%$ o $(2 \sigma, \mathrm{n}=6)$ at the $0.3 \mathrm{ka}$

414 sites. The HAc leachates display much lighter $\delta^{26} \mathrm{Mg}$ values at the sites older than $0.3 \mathrm{ka}$ (Table

415 2). Although the 'labile' $\mathrm{Mg}$ is depleted in light $\mathrm{Mg}$ isotopes, previous studies have shown that

416 labile Mg can be isotopically depleted (Opfergelt et al., 2012; Wimpenny et al., 2014) or

417 enriched in heavy Mg isotopes (Huang et al., 2012; Pogge Von Strandmann et al., 2012). At the

$418 \quad 0.3 \mathrm{ka}$ sites, $\delta^{26} \mathrm{Mg}$ values of all labile $\mathrm{Mg}$ are similar to that of Hawaiian basalt within errors.

419 Because $\mathrm{Mg}$ is an essential nutrient for plant growth, plants play an important role of its

420 recycling in the soil system, especially at the surface, as plants take up and release $\mathrm{Mg}$ during the

421 growth and decay, respectively. Both the organic-rich surface soils and labile fractions showed

422 an enrichment of $\mathrm{K}$ relative to $\mathrm{Na}$, when compared to $\mathrm{K} / \mathrm{Na}$ ratios of basalt $(0.24-0.39$; Ziegler et

423 al., 2005) and rainfall (0.05-0.18; Bern et al., 2015), suggesting that vegetation is transporting

424 biologically important elements to the surface (since Hawaiian plants have highly enriched K/Na 425 ratios (Trostle, 2014)). Plants preferentially accumulate heavy Mg isotopes in their tissues, 426 resulting in soil water depleted in heavy $\mathrm{Mg}$ isotopes (Black et al., 2008; Bolou-Bi et al., 2010, 427 2012). Since we did not detect $\mathrm{Mg}$ isotope fractionation of the 'labile' $\mathrm{Mg}$ in the $\mathrm{O}$ horizon at the 
428

429

430

431

432

433

434

435

436

437

438

439

440

441 could not exclude the effect of plant biocycling of $\mathrm{Mg}$ because both plant uptake and secondary

442 mineral formation causes soil water to be depleted in isotopically heavy $\mathrm{Mg}$. On the other hand,

$443 \delta^{26} \mathrm{Mg}$ values of residual $\mathrm{Mg}$ in the surface samples are quite variable, ranging from -0.44 to

$444+0.19 \%$. All these surface samples mainly contain SOM with little secondary phases (Table S2;

445 Ziegler et al., 2005). Previous studies have shown that the top $5 \mathrm{~cm}$ of the soil profiles exhibit a

446 shift toward more negative $\delta^{30} \mathrm{Si}$ values due to plant-related Si uptake and phytolith precipitation

447 (recycled biogenic silica) in the topsoil (Derry et al., 2005; Ziegler et al., 2005). Likewise, a shift

448 toward more positive $\delta^{26} \mathrm{Mg}$ values in the organic-rich surface samples is likely to be plant-

449 related $\mathrm{Mg}$ uptake and litterfall decomposition. Indeed, previous studies have shown that plants

450 (e.g., particularly roots (Bolou-Bi et al., 2012) and aboveground vegetation (Trostle, 2014)) can 
451 be enriched in heavy Mg isotopes. However, more investigations are needed to confirm it in the 452 case of these Hawaiian ecosystems.

\subsubsection{The impact of vegetation on the labile $\mathrm{Mg}$}

At the two youngest sites, the 'labile' Mg of the subsurface soils display $\delta^{26} \mathrm{Mg}$ values 456 ranging from -0.29 to $-0.02 \%$, with an average of $-0.17 \pm 0.12 \%$ o $(2 \sigma, \mathrm{n}=25)$. Furthermore, the

457 water, $\mathrm{NH}_{4} \mathrm{Cl}$ and $\mathrm{HAc}$ leachates have similar average $\delta^{26} \mathrm{Mg}$ values of $-0.20 \%,-0.11 \%$, and $458-0.18 \%$, respectively (Table 2). The fact that all the leachates are close to the Hawaiian basalts 459 is likely due to the large concentration of Mg supplied by congruent basalt weathering, which 460 buffers the effect of $\mathrm{Mg}$ isotope fractionation by plants. An alternative is that the degree of $\mathrm{Mg}$ 461 isotope fractionation by Hawaiian plants may not be as large as what is known for

462 granite/sandstone-grown plants (Bolou-Bi et al., 2012), but we consider this explanation unlikely

463 because hydroponic experimental approaches and adsorption on organics also demonstrated 464 strong isotope fractionations (up to $+1.66 \%$; Bolou-Bi et al., 2010, 2012; Black et al., 2008).

465 At the $20 \mathrm{ka}$ site, water leachates of two subsurface samples have average $\delta^{26} \mathrm{Mg}$ value of $466-0.01 \pm 0.21 \% 0(2 \sigma, \mathrm{n}=2)$, ranging from -0.08 to $+0.06 \%$. This indicates that the solution (i.e., 467 soil water) is enriched in isotopically heavy Mg compared to Hawaiian basalt or rainwater (Fig. 4 468 and Table 2) and therefore a simple mixing of these two sources (basalt dissolution and rain)

469 cannot explain the isotopic values. In contrast, it has been shown that litterfall supplies organic 470 matter that is a key constituent of the soil exchange complex and thus a potential sink for $\mathrm{Mg}$

471 (Bolou-Bi et al., 2010, 2012; Opfergelt et al., 2014). Therefore, these results suggest that, since 472 litter decomposition could significantly affect the Mg biogeochemical cycle, it could also explain 
473 the shift towards heavy $\delta^{26} \mathrm{Mg}$ of the exchangeable or labile fraction (Bolou-Bi et al., 2012;

474 Opfergelt et al., 2014).

$475 \quad$ At the older sites $(\geq 20 \mathrm{ka})$, despite limited data, $\mathrm{Mg}$ isotope variations of the labile pool

476 are similar to the ones observed in the O horizon, as discussed above (Fig. 4). The $\delta^{26} \mathrm{Mg}$ values

477 of the 'labile' $\mathrm{Mg}$ range from -0.89 to $+0.06 \%$, with an average of $-0.52 \pm 0.49 \%$, $(2 \sigma, \mathrm{n}=17$;

478 Table 2). The water and $\mathrm{NH}_{4} \mathrm{Cl}$ leachates (exchangeable $\mathrm{Mg}$ ) have average $\delta^{26} \mathrm{Mg}$ value of

$479-0.45 \pm 0.56 \%$ o $(2 \sigma, \mathrm{n}=10)$, slightly heavier than the HAc leachate $(-0.63 \pm 0.28 \% 0,2 \sigma, \mathrm{n}=7)$. This

480 is much heavier than local rainwater and therefore these variations can also be partly attributed to

481 downward migration of dissolved organic matter and the plant-related $\mathrm{Mg}$ redistribution (Figs. 4

482 and 5), as evidenced in previous studies (e.g. Marin-Spiotta et al., 2011; Kramer et al., 2012;

483 Bullen and Chadwick, 2016). Furthermore, it cannot be explained by the mixing between local

484 rainwater and congruent dissolution of basalt because primary minerals were completely

485 consumed before $20 \mathrm{ka}$ (Vitousek et al., 1997; Kennedy et al., 1998). It is possible that Mg

486 isotope variations of the labile $\mathrm{Mg}$ at the older sites ( $\geq 20 \mathrm{ka})$ may reflect the plant-related $\mathrm{Mg}$

487 recycling of different tissues of plants with different $\mathrm{Mg}$ isotopic compositions (Bolou-Bi et al.,

488 2012). Indeed, plants drawing upon high levels of available nutrients in fertile sites (young- to

489 intermediate-aged sites) produce tissues with relatively high nutrient concentration and

490 decompose more rapidly than those from infertile sites (older sites; Vitousek et al., 1997); This

491 was shown for Ca isotopes (Wiegand et al., 2005). Further investigations are needed to quantify

492 more precisely $\mathrm{Mg}$ isotope fractionation by biological $\mathrm{Mg}$ recycling in the soil system, but this

493 study indicates that when the concentration of $\mathrm{Mg}$ is relatively low due to little basalt weathering

494 input, the isotopic composition of labile $\mathrm{Mg}$ is more likely to be influenced by plant-related $\mathrm{Mg}$

495 recycling rather than local rainwater. 
4.3. Different behavior of $\mathrm{Mg}$ isotopes in the residual $\mathrm{Mg}$

498 Contrary to labile $\mathrm{Mg}$, most of residual Mg plotted outside of a mixing plot, indicating 499 other processes, such as basalt weathering and secondary phase formation, may control their $\mathrm{Mg}$ 500 isotopic compositions (Fig. 5). In following sections, we discuss the mechanisms involved in 501 setting the isotopic signal in the residual $\mathrm{Mg}$.

\subsubsection{Basalt weathering}

We don't fully understand the controls on $\mathrm{Mg}$ isotope fractionation during weathering.

505 Two experimental studies have concluded that silicate dissolution causes dissolved phases to

506 have different $\mathrm{Mg}$ isotope composition compared to parent mineral/rock due to either isotope

507 fractionation or conservative mixing (Wimpenny et al., 2010; Ryu et al., 2011, 2016). For the

508 Hawaiian LSAG sites, other isotope systems, such as Si and Li isotopes (Ziegler et al., 2005;

509 Ryu et al., 2014), have revealed that basalt leaching does not fractionate those isotopes at the 0.3

510 ka sites. Therefore, the behavior of Mg isotopes at the two youngest sites provide a baseline for

511 evaluating Mg isotope fractionation during progressive basalt dissolution. For subsurface

512 samples at the $0.3 \mathrm{ka}$ sites, the differences in $\delta^{26} \mathrm{Mg}$ values between all labile $\mathrm{Mg}$ and bulk basalt

$513\left(\Delta^{26} \mathrm{Mg}_{\text {labile Mg-basalt }}\right)$ range from -0.02 to $+0.25 \%$, with an average of $+0.10 \pm 0.15 \%$ o $(2 \sigma, \mathrm{n}=13)$ at

514 the Th site and of $+0.10 \pm 0.09 \%$ o $(2 \sigma, \mathrm{n}=12)$ at the Ol site (Table 2 and Fig. $4 b)$. Likewise,

$515 \Delta^{26} \mathrm{Mg}_{\text {residual } \mathrm{Mg} \text {-basalt }}$ ranges from 0.00 to $+0.07 \%$, with an average of $+0.04 \pm 0.04 \%$ o $(2 \sigma, \mathrm{n}=5)$ at

516 the Th site and of $+0.04 \pm 0.06 \%(2 \sigma, \mathrm{n}=4)$ at the Ol site. Although labile $\mathrm{Mg}$ has a slightly heavy

$517 \delta^{26} \mathrm{Mg}$ value compared to bulk basalt, all results highlight that basalt weathering does not

518 fractionate $\mathrm{Mg}$ isotopes. Secondary mineral phases in these soils (up to $18 \mathrm{wt} \%$ of SRO minerals 
519 and 13 wt.\% of poorly crystalline; Ziegler et al., 2005) have little effect on Mg isotopic

520 compositions of both labile and residual $\mathrm{Mg}$, which seem to be set by the basalt isotopic

521 signature. In short, no difference in $\delta^{26} \mathrm{Mg}$ values between soil and basalt at the two youngest

522 sites confirms that $\mathrm{Mg}$ isotope fractionation is negligible during basalt weathering under natural

523 conditions. Fractionation processes are imposed by soil and ecosystem processes acting on the

$524 \mathrm{Mg}$ once it is released from rock minerals.

\subsubsection{Secondary mineral formation}

As elements are being leached from basalt, the remaining element configurations become more stable: soil minerals evolve first to SRO minerals (e.g., allophane and ferrihydrite), sesquioxides (hematite and goethite), and then to crystalline products, such as goethite, gibbsite and kaolin minerals (Vitousek et al., 1997; Chorover et al. 2004; Ziegler et al., 2005). To date,

531 although many experimental and field studies have investigated $\mathrm{Mg}$ isotope fractionation during 532 secondary mineral formation, the reported directions are not yet clear (e.g., Wimpenny et al.,

533 2010, 2014; Huang et al., 2012; Liu et al., 2014; Opfergelt et al., 2014; Ryu et al., 2016; Gao et

534 al., 2018; Hindshaw et al., 2020). As detailed below, our results for the Hawaiian soils are 535 consistent with enrichments in heavy isotopes during secondary phases formation.

536 First, at the 20 ka site, the soils contain mostly SOM, chemically active SRO minerals

537 (allophane and ferrihydrite) and sesquioxide phases (goethite and hematite), in which SRO

538 minerals combined with SOM could adsorb labile Mg onto their surfaces (Chorover et al., 2004),

539 implying that the complexes of SRO minerals combined with SOM control the Mg retention

540 capacity on the soil exchange complex. As discussed in section 4.4.2, the two water leachates

541 significantly enriched in heavy $\mathrm{Mg}$ isotopes $(-0.01 \pm 0.21 \%, 2 \sigma, \mathrm{n}=2)$ compared to Hawaiian 
542 basalt or rainwater likely reflect plant recycling. However, we cannot exclude the possibility that

$543 \mathrm{Mg}$ isotope fractionation occurred during adsorption onto oxides - we did not conduct $\mathrm{Mg}$

544 isotope sorption experiments to evaluate that possibility. Furthermore, residual $\mathrm{Mg}$ in the

545 subsurface samples at the $20 \mathrm{ka}$ site showed much heavier $\delta^{26} \mathrm{Mg}$ values of $-0.03 \pm 0.08 \%$ o $(2 \sigma$,

$546 \mathrm{n}=3$ ) compared to bulk basalt (Figs. 2c \& 4b and Table 2). Although Opfergelt et al. (2014)

547 suggested that Mg cannot be easily incorporated into the octahedral sites of SRO minerals

548 (allophane), other studies showed that Mg in the SRO extraction through the treatment with

549 oxalate in the dry soils on Kohala displayed much heavier $\delta^{26} \mathrm{Mg}$ values compared to Hawaiian

550 basalt (Trostle, 2014) and that $\delta^{26} \mathrm{Mg}$ in bauxites correlates with gibbsite abundance (Liu et al.,

551 2014), indicating that either nanocrystalline (SRO) and/or crystalline $\mathrm{Fe}-$ and Al-phases (i.e.

552 goethite/hematite and gibbsite) may be responsible for enriched heavy Mg isotopes in residual

$553 \mathrm{Mg}$. Changes in bond lengths and vibrational frequencies in the octahedral sheets affect isotope

554 fractionation (Wang et al., 2017) as the crystal structure distorts to accommodate an ion with a

555 different charge and/or radius (Laurora et al., 2011; Michalski et al., 2015). Therefore, during the

556 substitution of octahedrally coordinated Fe by Mg in goethite/hematite, the bond length from

557 substituting elements can be approximated as the sum of the ionic radii of the cation and of the 6-

558 fold coordination $\mathrm{O}^{2-}$ anion (Shannon, 1976) even if bond lengths are not always accurately

559 known. For example, because the ionic radii of octahedral $\mathrm{Mg}^{2+}(0.72 \AA)$ and $\mathrm{Fe}^{3+}(0.645 \AA)$ are

560 slightly different (Shannon, 1976), the average Mg-O bond length in goethite ( $2.095 \AA)$ is

561 longer than the average $\mathrm{Fe}-\mathrm{O}$ bond length ( 2.02 A; Changela et al., 2012) through cation

562 substitution, which is also longer than the average $\mathrm{Mg}-\mathrm{O}$ bond length in water ( 2.07 $\AA$; Carugo

563 et al., 1993; Bock et al., 1994; Pavlov et al., 1998). Likewise, gibbsite has two-thirds of its

564 octahedral sites filled with $\mathrm{Al}^{3+}$ and one-third unoccupied, allowing small cations (e.g., $\mathrm{Li}, \mathrm{Mg}$, 
$565 \mathrm{Ni}$ and $\mathrm{Co}$ ) to fit into the unoccupied octahedral voids without significant deformation of the 566 layer (Isupov, 1999). As we discussed above, the intercalated Mg-O length in gibbsite (2.105 $\AA$ )

567 is longer than the $\mathrm{Al}-\mathrm{O}$ length in gibbsite (1.92 $\AA$; Ladeira et al., 2001) or the average $\mathrm{Mg}-\mathrm{O}$

568 bond length in water $(2.072 \AA$ ) without substantial bond contraction (Isupov, 1999). Although

569 several studies proposed a general trend relating $\mathrm{Mg}-\mathrm{O}$ bond length to the direction of $\mathrm{Mg}$

570 isotope fractionation (e.g., Liu et al., 2014; Gao et al., 2018; Hindshaw et al., 2020), there does

571 not appear to be a strong correlation between average $\mathrm{Mg}-\mathrm{O}$ bond length and $\mathrm{Mg}$ isotope

572 fractionation in octahedral coordination (Schauble, 2011). Therefore, the fact that residual Mg is 573 enriched in heavy Mg isotopes is more likely to attributed to nanocrystalline (SRO) Fe- and Al-

574 phases rather than gibbsite although this would certainly deserve to be verified experimentally.

575 Contrary to the $20 \mathrm{ka}$ site, the $150 \mathrm{ka}$ soils at depth of $<30 \mathrm{~cm}$ contain large amounts of

576 Qtz and mica (depth-integrated $\tau_{\text {int }}=15 \mathrm{wt.} \%$; Ziegler et al., 2005), indicating significant impact

577 of dust input. The impact for Mg may be smaller because a) basalts have high initial Mg contents

578 and b) the isotopic contrast between radiogenic continental $\mathrm{Sr}$ and basaltic $\mathrm{Sr}$ is greater than

579 between dust and basalt sources which have similar $\delta^{26} \mathrm{Mg}$ values. If Asian dust has strongly

580 influenced samples, the soil samples should reflect Mg isotopic composition of Asian dust (Fig.

581 5). Previous studies indicated that the average composition of Asian dust delivered to Hawaii has

582 not varied over the last 4 million years spanning the Hawaii chronosequence (Kyte et al., 1993),

583 and that modern Asian dust largely reflects the average composition of upper continental crust

584 (UCC; Zieman et al., 1995). Furthermore, the fact that the difference in a weighted average

$585 \delta^{26} \mathrm{Mg}$ between the UCC $(-0.22 \%$; Li et al., 2010) and 20 sedimentary composites from eastern

586 China $(-0.16 \%$; Li et al., 2010) is within the analytical error of $\pm 0.1 \%$ ( $2 \sigma)$ indicates that $\mathrm{Mg}$

587 isotopic composition of Asian dust reflects that of UCC. Nonetheless, residual Mg in the 
588 subsurface samples yield a $\delta^{26} \mathrm{Mg}$ value of $+0.18 \pm 0.18 \%$ o $(2 \sigma, \mathrm{n}=4)$ much heavier than both 589 Hawaiian basalt and UCC (Figs. $2 d \& 4$ b). Instead, the subsurface soils also contain greater 590 amounts of chemically active SRO minerals, $\mathrm{Fe}$ - and Al-crystalline compounds, and poorly 591 crystalline kaolin minerals (Chadwick et al., 2003; Chorover et al., 2004; Ziegler et al., 2005). As 592 discussed above, the incorporation of $\mathrm{Mg}$ into both $\mathrm{SRO}$ and $\mathrm{Fe}-$ and $\mathrm{Al}$-crystalline phases 593 causes residual $\mathrm{Mg}$ to be enriched in heavy $\mathrm{Mg}$ isotopes at the $150 \mathrm{ka}$ site as well. 594 At the 1400 ka site, the subsurface soil samples mainly contain SRO minerals and 595 crystalline phases (i.e., gibbsite and kaolinite/halloysite; Chorover et al., 2004; Ziegler et al., 596 2005). For the subsurface soil samples, the residual $\mathrm{Mg}$ showed $\delta^{26} \mathrm{Mg}$ values ranging from $597+0.27$ to $+0.46 \%$, with an average of $+0.38 \pm 0.18 \%(2 \sigma, n=4)$, much heavier than basalts and 598 other younger sites (Figs. 2e \& 4b). This implies that the incorporation of Mg into the octahedral 599 sites of crystalline secondary minerals (i.e., kaolinite/halloysite) plays a key role, and that this 600 process favors an isotope fractionation towards heavy $\mathrm{Mg}$ isotopes (Fig. 5b). As discussed above, $601 \mathrm{Mg}$ could be incorporated into the octahedral sites of kaolinite/halloysite substituting for $\mathrm{Al}$ 602 because kaolinite/halloysite is a 1:1 continuous layered silicate composed of an octahedral layer 603 coordinated to a tetrahedral layer similar to lizardite (Ryu et al., 2016). Considering the Al-O 604 length in kaolinite ( 1.91 $\AA$; Bish, 1993), the incorporated Mg-O length in kaolinite $(\sim 2.095 \AA)$ 605 is longer than the average $\mathrm{Mg}-\mathrm{O}$ length in water ( 2.07 $\AA$; Carugo et al., 1993; Bock et al., 606 1994; Pavlov et al., 1998) due to the ionic radii of $\mathrm{Mg}^{2+}(0.72 \AA)$ and $\mathrm{Al}^{3+}(0.535 \AA$; Shannon, 607 1976). However, experimental study showed that the residual kaolinite is enriched in heavy $\mathrm{Mg}$ 608 isotopes compared to bulk kaolinite (+1.63\%; Wimpenny et al., 2014), implying that it is 609 difficult to relate $\mathrm{Mg}-\mathrm{O}$ bond length to the direction of $\mathrm{Mg}$ isotope fractionation when the 610 difference in bond length between two phases is small, and that the direction of $\mathrm{Mg}$ isotope 
611 fractionation could be dependent on local field conditions (Hindshaw et al., 2020). In short,

612 positive $\delta^{26} \mathrm{Mg}$ values of residual $\mathrm{Mg}$ in soil at the $1400 \mathrm{ka}$ site likely reflect additional $\mathrm{Mg}$

613 isotope fractionation caused by kaolinite/halloysite formation.

614 At the oldest-aged site (4100 ka), the subsurface soil samples mainly contain Al- and Fe-

615 crystalline compounds and crystalline kaolin minerals (i.e. goethite/hematite, gibbsite, and

616 kaolinite/halloysite) (Chorover et al., 2004; Ziegler et al., 2005). For the subsurface soil samples,

617 the residual $\mathrm{Mg}$ showed heavy $\delta^{26} \mathrm{Mg}$ values ranging from +0.13 to $+0.26 \%$, with an average of

$618+0.18 \pm 0.10 \%$ o $(2 \sigma, \mathrm{n}=5)$, evidencing that crystalline secondary phases (i.e. goethite, gibbsite and

619 kaolinite/halloysite) preferentially incorporate heavy Mg isotopes into their octahedral sites,

620 causing $\mathrm{Mg}$ isotope fractionation (Figs. $2 \mathrm{f} \& 4 \mathrm{~b}$ ). Previous Li isotope study suggested that

621 warmer and wetter conditions in the Pliocene enhance more congruent release of $\mathrm{Li}$ isotopes

622 during periods of more intensive weathering of the basaltic rocks (Ryu et al., 2014). Likewise,

623 this process may explain the $4100 \mathrm{ka}$ soils have relatively lighter $\delta^{26} \mathrm{Mg}$ compared to the $1400 \mathrm{ka}$

624 soils. Otherwise, gibbsite may lead to larger Mg isotope fractionation rather than kaolinite

625 because 1400 ka soils contain more gibbsite than 4100 ka soils (Ziegler et al., 2005), but this

626 remains to be rigorously demonstrated.

627 Overall, based on our dataset, $\delta^{26} \mathrm{Mg}$ values at sites older than $20 \mathrm{ka}$ would be controlled

628 mainly by $\mathrm{Mg}$ isotope fractionation through crystallographical evolution from $\mathrm{Fe}-$ and $\mathrm{Al}-$

629 crystalline compounds (i.e., goethite/hematite and gibbsite) to kaolin minerals (kaolinite and

630 halloysite). Although it is not possible to quantitatively estimate the degree of $\mathrm{Mg}$ isotope

631 fractionation during basalt weathering and secondary minerals transformations in the Hawaiian

632 chronosequence, it appears that crystalline secondary phases preferentially incorporate heavy $\mathrm{Mg}$

633 isotopes during their transformations, confirming the close relation between the $\mathrm{Mg}-\mathrm{O}$ bond 
634 length and the direction of $\mathrm{Mg}$ isotope fractionation (Hindshaw et al., 2020). Furthermore, the

635 results indicate that the degree of $\mathrm{Mg}$ isotope fractionation is mainly attributed to secondary

636 mineral transformations as a function of soil age.

\subsection{Comparison with other studies}

639 The LSAG has been very well-studied in several isotope systems, such as $\mathrm{Ca}, \mathrm{Si}, \mathrm{Li}$

640 isotopes (Wiegand et al., 2005; Ziegler et al., 2005; Ryu et al., 2014; Bullen and Chadwick,

641 2016) in order to decipher biogeochemical processes involved in the terrestrial element cycle,

642 and highlight the role of basalt weathering and secondary mineral transformation. In particular,

643 Wiegand et al. (2005) examined ${ }^{87} \mathrm{Sr} /{ }^{86} \mathrm{Sr}$ ratios and Ca isotopes along the LSAG to see how

644 different alkaline earth elements behave, highlighting the effects of both marine aerosol and plant

645 cycling on $\mathrm{Ca}$ isotopes. As shown for $[\mathrm{Mg}]$ and its isotopic composition of labile $\mathrm{Mg}$ in this

646 study, they indicated that both exchangeable and total $\mathrm{Ca}$ pool decrease with age and that $\mathrm{Ca}$

647 isotopes in soil exchangeable pool are influenced by the mixture of marine aerosol and plant-

648 related Ca cycling. Likewise, Bullen and Chadwick (2016) analyzed Ba, Ca and Sr stable

649 isotopes along the Kohala climosequence and found that biocycling of these ions created a

650 negative fractionation that was maintained on the near-surface exchange complex, although with

651 differing affinities - Ba was most strongly held and $\mathrm{Ca}$ least strongly held against leaching.

652 Overall, stable isotope systems of alkaline earth elements can be powerful proxies for

653 deciphering their biogeochemical cycles.

654 As a relevant study, Trostle et al. (2014) investigated $\mathrm{Mg}$ isotopes at an arid $(\sim 30 \mathrm{~cm}$

655 MAP) soil chronosequence on the Island of Hawaii and highlighted the contribution of

656 pedogenic carbonate to light $\mathrm{Mg}$ isotopes in soils. Furthermore, they suggested that the evolution 
657 of the soil mineralogy and morphology during progressive soil development results in significant

658 changes in Mg isotopes through time, which is consistent with our study. Although there is little

659 effect of pedogenic carbonates on the isotopic composition of $\mathrm{Mg}$ in this study, both studies

660 indicate that basalt weathering and secondary mineral transformation plays an important role of

$661 \mathrm{Mg}$ isotopic compositions in soil system with little effect of Asian dust, incorporating heavy $\mathrm{Mg}$

662 isotopes into secondary phases. However, when compare the Mg isotope study conducted in

663 Iceland (Opfergelt et al., 2014) to our study that both are basaltic soil but different climate, there

664 are clear discrepancies between them. Opfergelt et al. (2014) showed that both exchangeable Mg

665 and clay fractions are depleted in heavy $\mathrm{Mg}$ isotopes compared to basalt although bulk soils are

666 isotopically similar to the parent basalt, highlighting the importance of Mg retention on the soil

667 exchange complex and the contribution of sea spray and vegetation (Fig. 5). While the soil

668 exchange complex is a key factor controlling Mg isotopes in both soil systems, in Iceland cold

669 conditions lead to slower weathering rates and development of crystalline secondary phases,

670 whereas in Hawaii there is fast secondary mineral transformation that enhances incorporation of

671 isotopically heavy $\mathrm{Mg}$ into crystalline secondary phases.

672

\section{5. CONCLUSIONS}

674 The Hawaiian Islands LSAG chronosequence allows us to better understand Mg isotope

675 fractionation during progressive basalt weathering and open-system biogeochemical

676 transformations in soil. Given the large concentration of $\mathrm{Mg}$ in basalts, the effect of atmospheric

677 deposition to the soil $\mathrm{Mg}$ budget for all the sites is small. The major fractionations to $\mathrm{Mg}$

678 isotopes in soils are strong plant-related changes to labile Mg, although there may be some effect

679 due to rainwater input and bond-length selectivities during incorporation of $\mathrm{Mg}$ into secondary 
$680 \mathrm{Al}-$ and $\mathrm{Fe}-$ oxyhydroxides. The variations of $\mathrm{Mg}$ isotopes in residual $\mathrm{Mg}$ mostly reveal $\mathrm{Mg}$

681 isotope fractionation during secondary mineral formation favoring heavy $\mathrm{Mg}$ isotopes. Two

682 youngest soils ( $0.3 \mathrm{ka}$; Th and $\mathrm{Ol})$ display $\delta^{26} \mathrm{Mg}$ values consistent with Hawaiian basalt,

683 regardless of labile and residual $\mathrm{Mg}$, indicating that basalt weathering results in little or no $\mathrm{Mg}$

684 isotope fractionation over $0.3 \mathrm{ka}$. However, residual $\mathrm{Mg}$ in the intermediate- and oldest-soils $(\geq$

$68520 \mathrm{ka}$ ) display more variable but much enriched $\delta^{26} \mathrm{Mg}$ values compatible with the known

686 mineralogical and crystallographical evolution of these profiles, suggesting that secondary

687 mineral transformation is a key process controlling $\mathrm{Mg}$ isotope fractionation. Overall, $\mathrm{Mg}$

688 isotope variations in labile and residual $\mathrm{Mg}$ of soils in Hawaiian LSAG are determined by the

689 effects of plant-related $\mathrm{Mg}$ recycling and incorporation of heavy $\mathrm{Mg}$ isotopes into

690 (nano)crystalline secondary phases.

691

692 ACKNOWLEDGMENTS

693 This work was supported by the National Research Foundation of Korea (NRF) grants funded by 694 the Korea government (MSIT) (No. NRF-2019R1A2C2085973). 


\section{REFERENCES}

696 Bern C.R., Chadwick O.A., Kendall C. and Pribil M.J. (2015) Steep spatial gradients of volcanic 697 and marine sulfur in Hawaiian rainfall and ecosystems. Sci. Total Environ. 514, 250-260. 698 Berner R.A., Lasaga A.C. and Garrels R.M. (1983) The carbonate-silicate geochemical cycle 699 and its effect on atmospheric carbon dioxide over the past 100 million years. Am. J. Sci. 283, 641-683.

Berner R.A. (2004) The Phanerozoic Carbon Cycle: $\mathrm{CO}_{2}$ and $\mathrm{O}_{2}$. Oxford University Press.

Bish D.L. (1993) Rietveld refinement of the kaolinite structure at 1.5 K. Clays Clay Miner. 41, 738-744.

Black J. R., Epstein E., Rains W. D., Yin Q. Z. and Casey W. H. (2008) Magnesium-isotope fractionation during plant growth. Environ. Sci. Technol. 42, 7831-7836.

Bock C.W., Kaufman A. and Glusker J.P. (1994) Coordination of water to magnesium cations. Inorg. Chem. 33, 419-427.

Bolou-Bi B.E., Vigier N., Leyval C. and Poszwa A. (2010) Experimental determination of magnesium isotope fraction- ation during higher plant growth. Geochim. Cosmochim. Acta 74, 2523-2537.

Bolou-Bi E.B., Vigier N., Poszwa A., Boudot J.-P. and Dambrine E. (2012) Effects of biogeochemical processes on magnesium isotope variations in a forested catchment in the Vosges Mountains (France). Geochim. Cosmochim. Acta 87, 341-355.

Brimhall G.H. and Dietrich W.E. (1987) Constitutive mass balance relations between chemical composition, volume, density, porosity, and strain in metasomatic hydrochemical systems: results on weathering and pedogenesis. Geochim. Cosmochim. Acta 51, 567587.

Bullen T. and Chadwick O.A. (2016) Ca, $\mathrm{Sr}$ and Ba stable isotopes reveal the fate of soil nutrients along a tropical climosequence in Hawaii. Chem. Geol. 422, 25-45.

Carrillo J.H., Hastings M.G., Sigman D.M. and Huebert B.J. (2002) Atmospheric deposition of 722 inorganic and organic nitrogen and base cations in Hawaii. Global Biogeochem. Cy. 16, 24-1-24-16. 
723 Carugo O., Djinović K. and Rizzi M. (1993). Comparison of the co-ordinative behaviour of 724 calcium(II) and magnesium(II) from crystallographic data. J. Chem. Soc. Dalton Trans. $725 \quad \mathbf{1 4}, 2127-2135$.

726 Chadwick O.A., Brimhall G.H. and Hendricks D.M. (1990) From a black to a gray box - a mass 727 balance interpretation of pedogenesis. Geomorphology 3, 369-390.

728 Chadwick O.A., Derry L.A., Vitousek P.M., Heubert B.J. and Hedin L.O. (1999) Changing 729 sources of nutrients during four million years of ecosystem development. Nature 397, $730 \quad 491-497$.

731 Chadwick O.A., Gavenda R.T., Kelly E.F., Ziegler K., Olson C.G., Crawford Elliott W. and 732 Hendricks D.M. (2003) The impact of climate on the biogeochemical functioning of 733 volcanic soils. Chem. Geol. 202, 195-223.

734 Chadwick O.A., Derry L.A., Bern C.R. and Vitousek P.M. (2009) Changing sources of strontium 735 to soils and ecosystems across the Hawaiian Islands. Chem. Geol. 267, 64-75.

736 Chan L.-H. and Hein J.R. (2007) Lithium contents and isotopic compositions of ferromanganese 737 deposits from the global ocean. Deep-Sea Res. II 54, 1147-1162.

738 Changela H.G., Bridges J.C. and Gurman S.J. (2012) Extended X-ray Absorption Fine Structure 739 (EXAFS) in Stardust tracks: constraining the origin of ferric iron-bearing minerals.

740 Geochim. Cosmochim. Acta 98, 282-294.

741 Chorover J., DeChiaro M.J. and Chadwick O.A. (1999) Structural charge and cesium retention in 742 a chronosequence of tephritic soils. Soil Sci. Soc. Am. J. 63, 169-177.

743 Chorover J., Amistandi M.K. and Chadwick O.A. (2004) Surface charge evolution of mineral744 organic complexes during pedogenesis in Hawaiian basalt. Geochim. Cosmochim. Acta $745 \quad 68,4859-4876$.

746 Crews T.E., Kitayama K., Fownes J.H., Riley R.H., Herbert D.A., Mueller-Dombois D. and 747 Vitousek P.M. (1995) Changes in soil phosphorus fractions and ecosystem dynamics 748 across a long chronesquence in Hawaii. Ecology 76, 1407-1424.

749 de Villiers S. and Nelson B.K. (1999) Detection of low temperature hydrothermal fluxes by $750 \quad$ seawater $\mathrm{Mg}$ and $\mathrm{Ca}$ anomalies. Science 285, 721-723.

751 Derry L.A., Kurtz A.C., Ziegler K. and Chadwick O. (2005) Biological control of terrestrial 752 silica cycling and export fluxes to shtersheds. Nature 433, 728-731. 
753 Dessert C., Dupré B., François L.M., Schott J., Gaillardet J., Chakrapani G. and Bajpai S. (2001) 754 Erosion of Deccan Traps determined by river geochemistry: impact on the global climate 755 and the ${ }^{87} \mathrm{Sr} /{ }^{86} \mathrm{Sr}$ ratio of seawater. Earth and Planet. Sci. Lett. 188, 459-474.

756 Dessert C., Dupré B., Gaillardet J., François L.M. and Allègre C.J. (2003) Basalt weathering 757 laws and the impact of basalt weathering on the global carbon cycle. Chem. Geol. 202, $758 \quad 257-273$.

759 Fiske R.S., Rose T.R., Swanson D.A., Champion D.E. and McGeehin J.P. (2009) Kulanaokuaiki 760 Tephra (ca. A.D. 400-1000): Newly recognized evidence for highly explosive eruptions 761 at Kilauea Volcano, Hawaii. Geol. Soc. Am. Bull. 121, 712-728.

762 Galy A., Belshaw N.S., Halicz L. and O'Nions R.K. (2001) High-precision measurement of 763 magnesium isotopes by multiple-collector inductively coupled plasma mass $764 \quad$ spectrometry. Int. J. Mass Spectrom. 208, 89-98.

765 Galy A., Yoffe O., Janney P.E., Williams R.W., Cloquet C., Alard O., Halicz L., Wadhwa M., 766 Hutcheon I.D., Ramon E. and Carignan J. (2003) Magnesium isotope heterogeneity of the 767 isotopic standard SRM980 and new reference materials for magnesium-isotope-ratio 768 measurements. J. Anal. At. Spectrom. 18, 1352-1356.

769 Gao T., Ke S., Wang S.-J., Li F., Liu C., Lei J., Liao C. and Wu F. (2018) Constrasting Mg 770 isotopic compositions between Fe-Mn nodules and surrounding soils: Accumulation of 771 light Mg isotopes by Mg-depleted clay minerals and Fe oxides. Geochim. Cosmochim. $772 \quad$ Acta 237, 205-222.

773 Goodfellow B.W., Hilley G.E. and Chadwick O.A. (2013) Depth and character of rock 774 weathering across basalt-hosted climo- sequences on Hawaii and Kauai. Earth Surf. 775 Process. Landf. http://dx.doi.org/10.1002/esp.3505.

776 Hall P.L., Churchman G.J. and Theng B.K.G. (1985) Size distribution of allophane unit particles 777 in aqueous suspensions. Clays Clay Miner. 33, 345-349.

778 Hindshaw R.S., Tosca R., Tosca N.J. and Tipper E.T. (2020) Experimental constraints on Mg 779 isotope fractionation durng clay formation: Implications for the global biogeochemical $780 \quad$ cycle of Mg. Earth and Planet. Sci. Lett. 531, 115980.

781 Huang F., Glessner J., Ianno A., Lundstrom C. and Zhang Z. (2009) Magnesium isotopic 782 composition of igneous rock standards measured by MC-ICP-MS. Chem. Geol. 268, 1578323. 
784 Huang K.-J., Teng F.-Z., Wei G.-J., Ma J.-L. and Bao Z.-Y. (2012) Adsorption- and desorptioncontrolled magnesium isotope fractionation during extreme weathering of basalt in Hainan Island, China. Earth and Planet. Sci. Lett. 359-360, 73-83.

Isupov V.P. (1999) Intercalation compounds of aluminum hydroxide. J. Struct. Chem. 40, 672685.

Jacobson A.D. and Blum J.D. (2000) Ca/Sr and ${ }^{87} \mathrm{Sr} /{ }^{86} \mathrm{Sr}$ geochemistry of disseminated calcite in Himalayan silicate rocks from Nanga Parbat: Influence on river water chemistry. Geology 28, 463-466.

Kramer M.G., Sanderman J., Chadwick O.A., Chorover J. and Vitousek P.M. (2012) Long-term carbon storage through retention of dissolved aromatic acids by reactive particles in soil. Global Change Biology doi: 10.1111/j.1365-2486.2012.02681.x

Kurtz A.C., Derry L.A., Chadwick O.A. and Alfano M.J. (2000) Refractory element mobility in volcanic soils. Geology 28, 683-686.

Kurtz A.C., Derry L.A. and Chadwick O.A. (2001) Accretion of Asian dust to Hawaiian soils: Isotopic, elemental, and mineral mass balances. Geochim. Cosmochim. Acta 65, 19711983.

Kyte F.T., Leinen M., Ross Heath G. and Zhou L. (1993) Cenozoic sedimentation history of the

812 Lee S.-W., Ryu J.-S. and Lee K.-S. (2014) Magnesium isotope geochemistry in the Han River, central North Pacific: inferences from the elemental geochemistry of core LL44- GPC3. Geochim. Cosmochim. Acta 57, 1719-1740.

Ladeira A.C.Q., Ciminelli V.S.T., Duarte H.A., Alves M.C.M. and Ramos A.Y. (2001) Mechanism of anion retention from EXAFS and density functional calculations: Arsenic (V) adsorbed on gibbsite. Geochim. Cosmochim. Acta 65, 1211-1217.

Laurora A., Brigatti M.F., Malferrari D., Galli E. and Rossi A. (2011) The crystal chemistry of lizardite-1T from northern Apennines ophiolites near Modena, Italy. Can. Mineral. 49, 1045-1054. South Korea. Chem. Geol. 364, 9-19. 
814 Li W.-Y., Teng F.-Z., Ke S., Rudnick R.L., Gao S., Wu F.-Y. and Chappell B.W. (2010)

815 Heterogeneous magnesium isotopic composition of the upper continental crust. Geochim.

$816 \quad$ Cosmochim. Acta 74, 6867-6884.

817 Li W., Beard B.L., Li C. and Johnson C.M. (2014) Magnesium isotope fractionation between

818 brucite $\left[\mathrm{Mg}(\mathrm{OH})_{2}\right]$ and $\mathrm{Mg}$ aqueous species: Implications for silicate weathering and

819 biogeochemical processes. Earth and Planet. Sci. Lett. 394, 82-93.

820 Ling M.-X., Sedaghatpour F., Teng F.-Z., Hays P.D., Strauss J. and Sun W. (2011) Homogenous

821 magnesium isotopic composition of seawater: an excellent geostandard for $\mathrm{Mg}$ isotope

822 analysis. Rapid Commun. Mass Spectrom. 25, 2828-2836.

823 Liu X.-M., Teng F.-Z., Rudnick R.L., McDonough W.F. and Cummings M. (2014) Massive

824 magnesium depletion and isotopic fractionation in weathered basalts. Geochim.

$825 \quad$ Cosmochim. Acta 135, 336-349.

826 MacDonald G., Abbott A.T. and Peterson F.L. (1983) Volcanoes in the sea: The geology of

$827 \quad$ Hawaii. University of Hawaii Press.

828 Marin-Spiotta E., Chadwick O.A., Kramer M. and Carbone M.S. (2011) Carbon delivery to deep

829 mineral horizons in Hawaiian rainforest soils. JGR-Biogeoscience

830 doi:10.1029/2010JG001587

831 McPhie J., Walker G.P.L. and Christiansen R.L. (1990) Phreatomagmatic and phreatic fall and

832 surge deposits from explosions at Kilauea volcano, Hawaii, 1790 A.D.: Keanakakoi Ash

833 Member. Bull. Volcanol. 52, 334-354.

834 Mermut A.R. and Cano A.F. (2001) Baseline studies of the clay minerals society source clays:

835 chemical analyses of major elements. Clays Clay Miner. 49, 381-386.

836 Michalski J.R., Cuadros J., Bishop J.L., Dyar M.D., Dekov V. and Fiore S. (2015) Constraints on

837 the crystal-chemistry of Fe/Mg-rich smectitic clays on Mars and links to global alteration

$838 \quad$ trends. Earth Planet. Sci. Lett. 427, 215-225.

839 Misra S. and Froelich P.N. (2012) Lithium Isotope History of Cenozoic Seawater: Changes in

$840 \quad$ Silicate Weathering and Reverse Weathering. Science 335, 818-823.

841 Opfergelt S., Georg R., Delvaux B., Cabidoche Y. M., Burton K. and Halliday A. (2012)

842 Mechanisms of magnesium isotope fractionation in volcanic soil weathering sequences,

843 Guade- loupe. Earth Planet. Sci. Lett. 341, 176-185. 
844 Opfergelt S., Burton K.W., Georg R.B., West A.J., Guicharnaud R.A., Sigfusson B., Siebert C., Gislason S.R. and Halliday A.N. (2014) Magnesium retention on the soil exchange complex controlling $\mathrm{Mg}$ isotope variations in soils, soil solutions and vegetation in volcanic soils, Iceland. Geochim. Cosmochim. Acta 125, 110-130.

Pavlov M., Siegbahn P.E.M. and Sandström M. (1998) Hydration of beryllium, magnesium, calcium, and zinc ions using density functional theory. J. Phys. Chem. A 102, 219-228.

Peskleway C.D., Henderson G.S. and Wick F.J. (2003) Dissolution of gibbsite: Direct observations using fluid cell atomic force microscopy. Am. Mineral. 88, 18-26.

Pett-Ridge J.C., Monastra V., Derry L.A. and Chadwick O.A. (2007) Importance of atmospheric inputs and Fe-oxides in controlling soil uranium budgets and behavior along a Hawaiian chronosequence. Chem. Geol. 244, 691-707.

Pogge von Strandmann P.A.E., Opfergelt S., Lai Y.J., Sigfu' sson B., Gislason S.R. and Burton

Pogge von Strandmann P.A.E., Burton K.W., James R.H., van Calsteren P., Gislason S.R. and Sigfússon B. (2008) The influence of weathering processes on riverine magnesium

Pogge von Strandmann P.A.E., Jenkyns H.C. and Woodfine R.G. (2013). Lithium isotope evidence for enhanced weathering during Oceanic Anoxic Event 2. Nat. Geosci. 6, 668672.

Rudnick R.L. and Gao S. (2003) Composition of the continental crust. In: Rudnick RL (Ed.) The

Ryu J.-S., Jacobson A.D., Holmden C., Lundstrom C. and Zhang Z. (2011) The major ion, K.W. (2012) Lithium, magnesium and silicon isotope behaviour accompanying weathering in a basaltic soil and pore water profile in Iceland. Earth Planet. Sci. Lett. 339, 11-23. isotope geochemistry during basalt weathering and secondary mineral transformations in Hawaii. Geochim. Cosmochim. Acta 145, 103-115. 
874 Ryu J.-S., Vigier N., Decarreau A., Lee S.-W., Lee K.-S., Song H. and Petit S. (2016)

875 Experimental investigation of $\mathrm{Mg}$ isotope fractionation during mineral dissolution and 876 clay formation. Chem. Geol. 445, 135-145.

877 Schwertmann U. and Taylor R.M. (1989) Iron oxides. In: Dixon, J.B., and Weed, S.B., (Eds.) 878 Minerals in Soil Environments. 2nd ed., Soil Science Society of America Book Series 1.

879 Shannon R.D. (1976) Revised effective ionic radii and systematic studies of interatomic 880 distances in halides and chalcogenides. Acta Cryst. A32, 751-767.

881 Stewart B.W., Capo R.C., and Chadwick O.A. (2001) Effects of precipitation on weathering rate, 882 base cation provenance and $\mathrm{Sr}$ isotope composition in a volcanic soil climosequence, 883 Hawaii. Geochimica et Cosmochimica Acta 65, 1087-1099.

884 Teng F.-Z., Li W.-Y., Rudnick R.L. and Gardner L.R. (2010) Contrasting behavior of lithium 885 886 and magnesium isotope fractionation during continental weathering. Earth Planet. Sci. Lett. 300, 63-71.

887 Teng F.-Z. (2017) Magnesium Isotope Geochemistry. Rev. Mineral. Geochem. 82, 218-287.

888 Tipper E.T., Galy A. and Bickle M.J. (2006) Riverine evidence for a fractionated reservoir of Ca 889 and Mg on the continents: Implications for the oceanic Ca cycle. Earth Planet. Sci. Lett. $890 \quad 247,267-279$.

891 Tipper E.T., Galy A. and Bickle M.J. (2008a) Calcium and magnesium isotope systematics in 892 rivers draining the Himalaya-Tibetan-Plateau region: Lithological or fractionation 893 control? Geochim. Cosmochim. Acta 72,1057-1075.

894 Tipper E.T., Louvat P., Capmas F., Galy A. and Gaillardet J. (2008b) Accuracy of stable Mg and 895 Ca isotope data obtained by MC-ICP-MS using the standard addition method. Chem. 896 Geol. 257, 65-75.

897 Trostle K. (2014) Weathering And Magnesium Isotope Fractionation In Arid Hawaiian Soils. Ph. 898 D. thesis, Cornell Univ.

899 Vigier N., Gislason S.R., Burton K.W., Millot R. and Mokadem F. (2009) The relationship 900 between riverine lithium isotope composition and silicate weathering rates in Iceland. $901 \quad$ Earth and Planet. Sci. Lett. 287, 434-441.

902 Vitousek P.M., Chadwick O.A., Crew T.E., Fownes J.H., Hendricks D.M. and Herbert D. (1997) 903 Soil and Ecosystem Development Across the Hawaiian Islands. GSA TODAY 7, 1-9. 
904 Vitousek P.M. (2004) Nutrient cycling and limitation: Hawaii as a model system. Princeton $905 \quad$ University Press, Princeton, New Jersey, USA.

906 Wang W., Qin T., Zhou C., Huang S., Wu Z. and Huang F. (2017) Concentration effect on 907 equilibrium fractionation of $\mathrm{Mg}-\mathrm{Ca}$ isotopes in carbonate minerals: insights from first908 principles calculations. Geochim. Cosmochim. Acta 208, 185-197.

909 Wiegand B.A., Chadwick O.A., Vitousek P.M. and Wooden J.L. (2005) Ca cycling and isotopic 910 fluxes in forested ecosystems in Hawaii. Geophys. Res. Lett. 32: L11404, 911 doi:10.1029/2005GL022746.

912 Wimpenny J., Gislason S.R., James R.H., Gannoun A., Pogge von Strandmann P.A.E. and 913 Burton K.W. (2010) The behaviour of Li and Mg isotopes during primary phase 914 dissolution and secondary mineral formation in basalt. Geochim. Cosmochim. Acta 74,

916 Wimpenny J., Colla C.A., Yin Q.-Z., Rustad J.R. and Casey W.H. (2014) Investigating the 917 behaviour of $\mathrm{Mg}$ isotopes during the formation of clay minerals. Geochim. Cosmochim. $918 \quad$ Acta 128, 178-194.

919 Wolfe E.W. and Morris J. (1996) Geologic Map of the Island of Hawaii. US Geological Survey $920 \quad$ Miscellaneous Investigations Map I-2524.

921 Wright T.L. and Heltz R.T. (1986) Differentiation and magma mixing on Kilauea's east rift zone: 922 a further look at the eruptions of 1955 and 1960. Part II. The 1960 lavas. Bull. Volcanol. $923 \quad \mathbf{5 7}, 602-630$.

924 Young E.D. and Galy A. (2004) The isotope geochemistry and cosmochemistry of magnesium. 925 Rev. Mineral. Geochem. 55, 197-230.

926 Zhong Y., Chen L.-H., Wang X.-J., Zhang G.-L., Xie L.-W. and Zeng G. (2017) Magnesium 927 isotopic variation of oceanic island basalts generated by partial melting and crustal 928 recycling. Earth and Planet. Sci. Lett. 463, 127-135.

929 Ziegler K., Chadwick O.A., Brzezinski M.A. and Kelly E.F. (2005) Natural variations of $\delta^{30} \mathrm{Si}$ 930 ratios during progressive basalt weathering, Hawaiian Islands. Geochim. Cosmochim. $931 \quad$ Acta 69, 4597-4610.

932 Zieman J.J., Holmes J.L., Connor D., Jensen C.R. and Zoller W.H. (1995) Atmospheric erosol 933 trace element chemistry at Mauna Loa Observatory. J. Geophys. Res. 100, 25979-25994. 


\section{FIGURE CAPTIONS}

935 Figure 1. Elemental concentrations and the elemental gain $\left(\tau_{j, w}>0\right)$ or $\operatorname{loss}\left(\tau_{j, w}<0\right)$ versus depth. (a)-(c) Concentrations of $\mathrm{Mg}, \mathrm{Al}$ and Fe in each soil profile. (d)-(f) $\tau_{M g}$ is calculated using Eq. (1). All $[\mathrm{Mg}],[\mathrm{Al}],[\mathrm{Fe}]$ and $[\mathrm{Nb}]$ data in parent basalts are from

Figure 2. Magnesium isotope compositions versus depth. The black and blue lines represent Ziegler et al. (2005). (see text for more details). average $\delta^{26} \mathrm{Mg}$ values of $-0.26 \%$ (Hawaiian basalts; Zhong et al., 2017) and $-0.83 \%$ o

Figure 3. Depth-integrated parameters versus age. (a) The $\mathrm{Mg}$ gain or loss $\left(\tau_{M g}\right)$, (b) $\delta^{26} \mathrm{Mg}$, (c)average $\delta^{26} \mathrm{Mg}$ value of $-0.26 \%$ in Hawaiian basalts (Zhong et al., 2017). Error bars are smaller than the symbols.

946 Figure 4. Magnesium isotopic compositions in the labile and residual $\mathrm{Mg}$ as a function of age. seawater (blue; $-0.83 \%$; Ling et al., 2011), basalt (black; $-0.26 \%$; Zhong et al., 2017),

951 Figure 5. $\delta^{26} \mathrm{Mg}$ values versus $1 /[\mathrm{Mg}]\left(\mathrm{wt} \%^{-1}\right)$ for the labile and residual $\mathrm{Mg}$ in all soil samples 952 measured in this study. Asian dust $\delta^{26} \mathrm{Mg}$ is assumed to be equal to the upper continental 953 crust (UCC) $\delta^{26} \mathrm{Mg}(-0.22 \%$; Li et al., 2010) with [Mg] of 1.5 wt.\% (Rudnick and Gao,

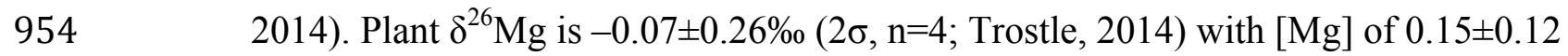
955 wt. $\%\left(2 \sigma, n=4\right.$; Trostle, 2014), $\operatorname{SOM} \delta^{26} \mathrm{Mg}$ is $+0.06 \pm 0.48 \%$ o $(2 \sigma, \mathrm{n}=4$; Trostle, 2014) 
with $[\mathrm{Mg}]$ of $0.03 \pm 0.02 \mathrm{wt} . \%(2 \sigma, \mathrm{n}=4$; Trostle, 2014$)$, rainwater $\delta^{26} \mathrm{Mg}$ is assumed to be equal to seawater $\delta^{26} \mathrm{Mg}(-0.83 \%$; Ling et al., 2011) with [Mg] of $0.09 \pm 0.11 \mathrm{ppm}(2 \sigma$, $\mathrm{n}=6$; Carrillo et al., 2002), and Hawaiian basalts $\delta^{26} \mathrm{Mg}$ is $-0.26 \pm 0.06 \%$ o $(2 \sigma, \mathrm{n}=11$; Zhong et al., 2017) with $[\mathrm{Mg}]$ of $4.7 \pm 1.6$ wt. $\%(2 \sigma, \mathrm{n}=10$; Zhong et al., 2017). The grey shaded field marks the mixing zone between each considered end-member. Error bars for soil samples are smaller than the symbols. Data for a cross symbol are from Opfergelt et al. (2014). Symbols are the same as in Fig. 2.

963

964 Figure S1. Map of the Hawaiian Islands showing the sampling locations and their substrate ages (Modified from Crews et al., 1995).

966 Figure S2. Fraction of each end-member (basalt, dust and rainwater) relative to the total $\mathrm{Mg}(\%)$ 967 versus age. Error bars represent $1 \sigma$, propagated using the range of $[\mathrm{Mg}]$ for each end968 member (see text for more details). 

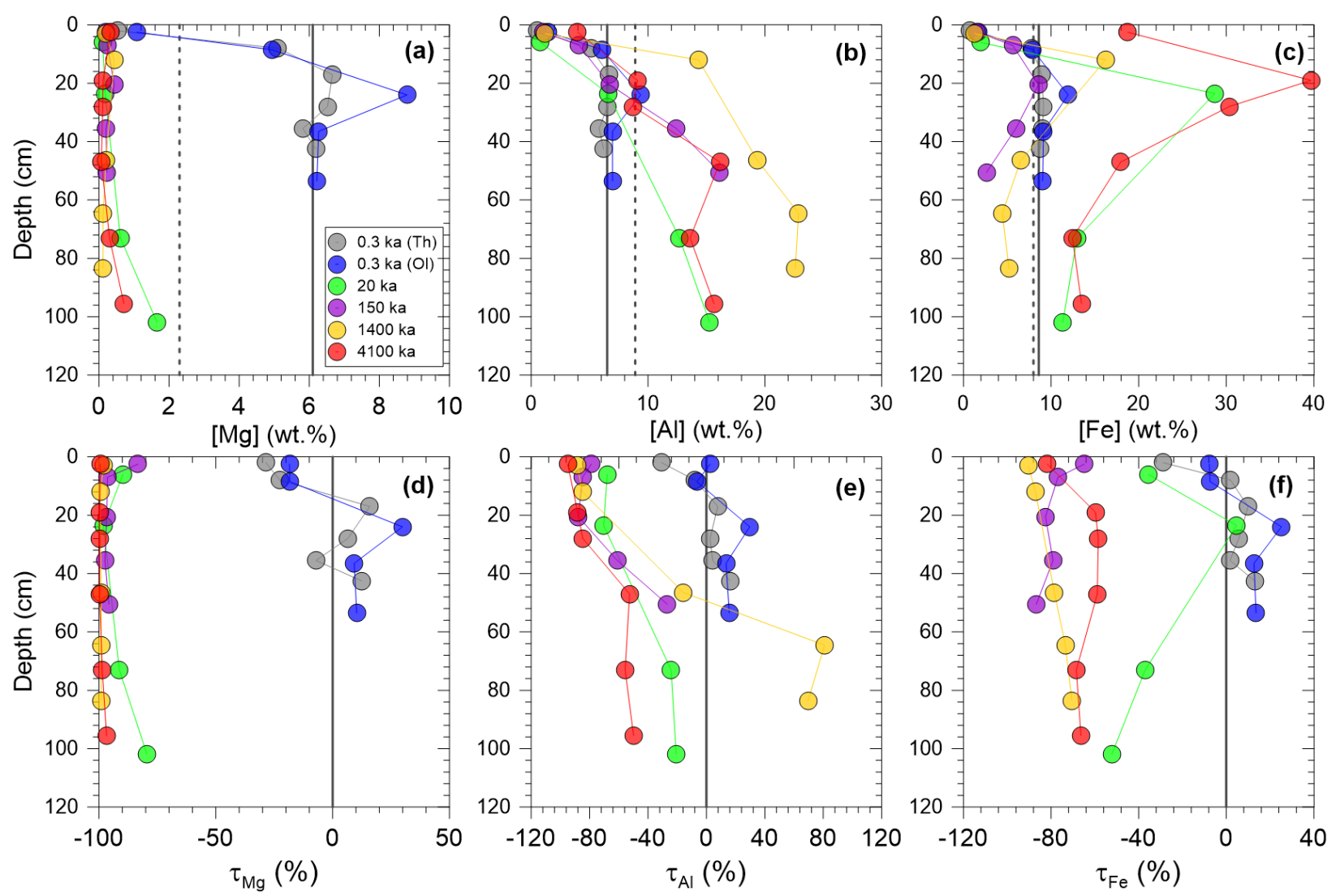

Fig. 1. Ryu et al. 

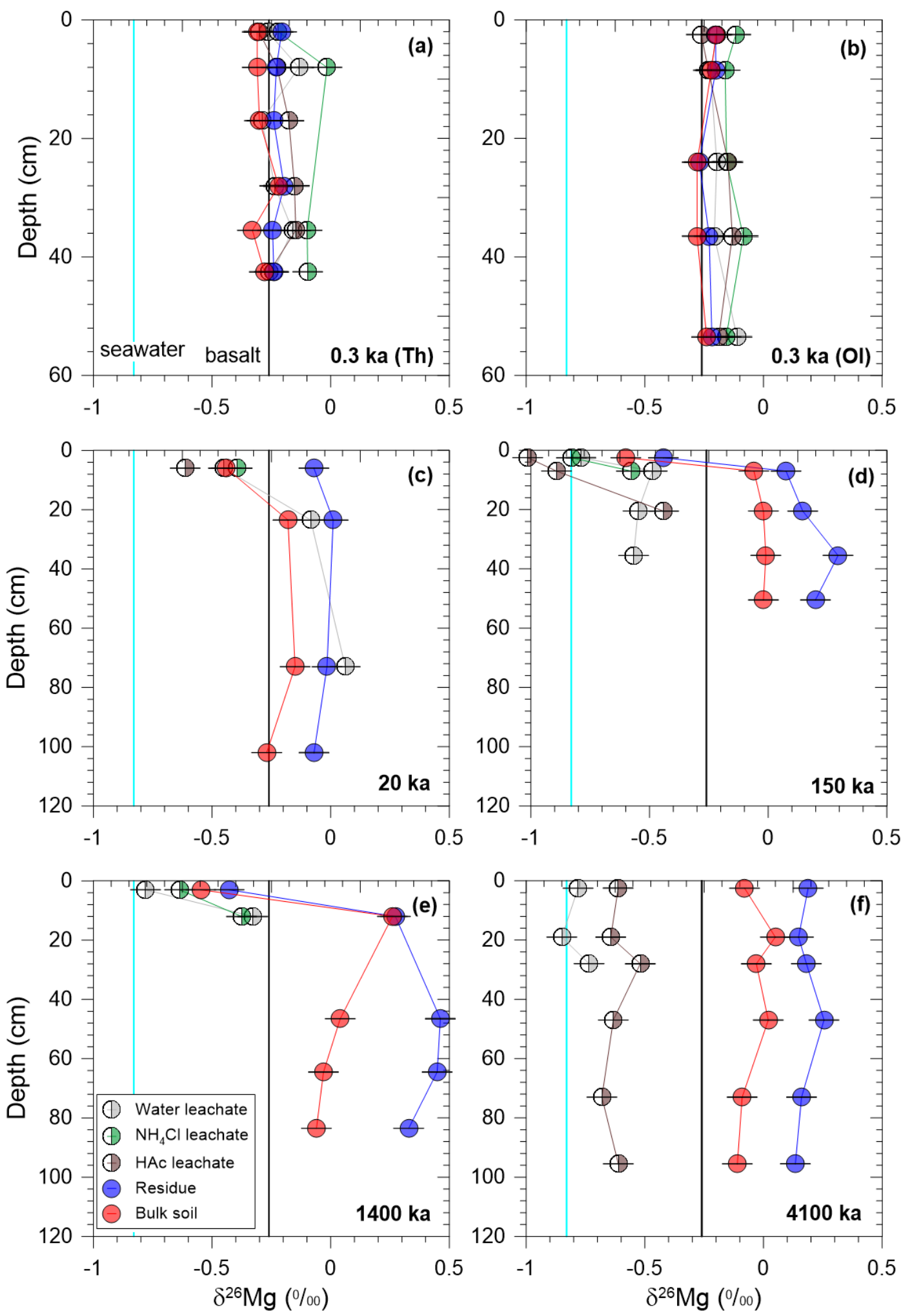

Fig. 2. Ryu et al. 

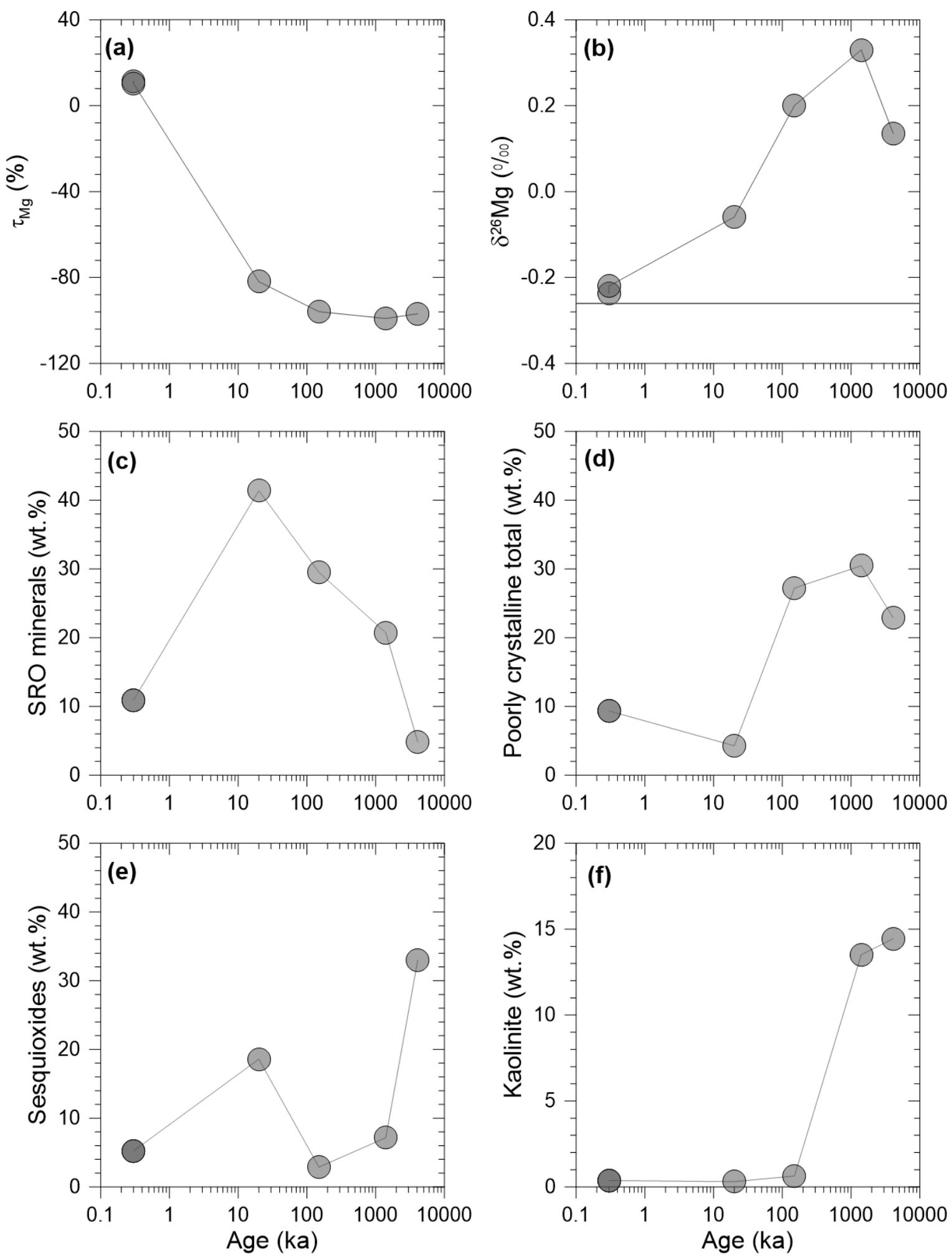

Fig. 3. Ryu et al. 

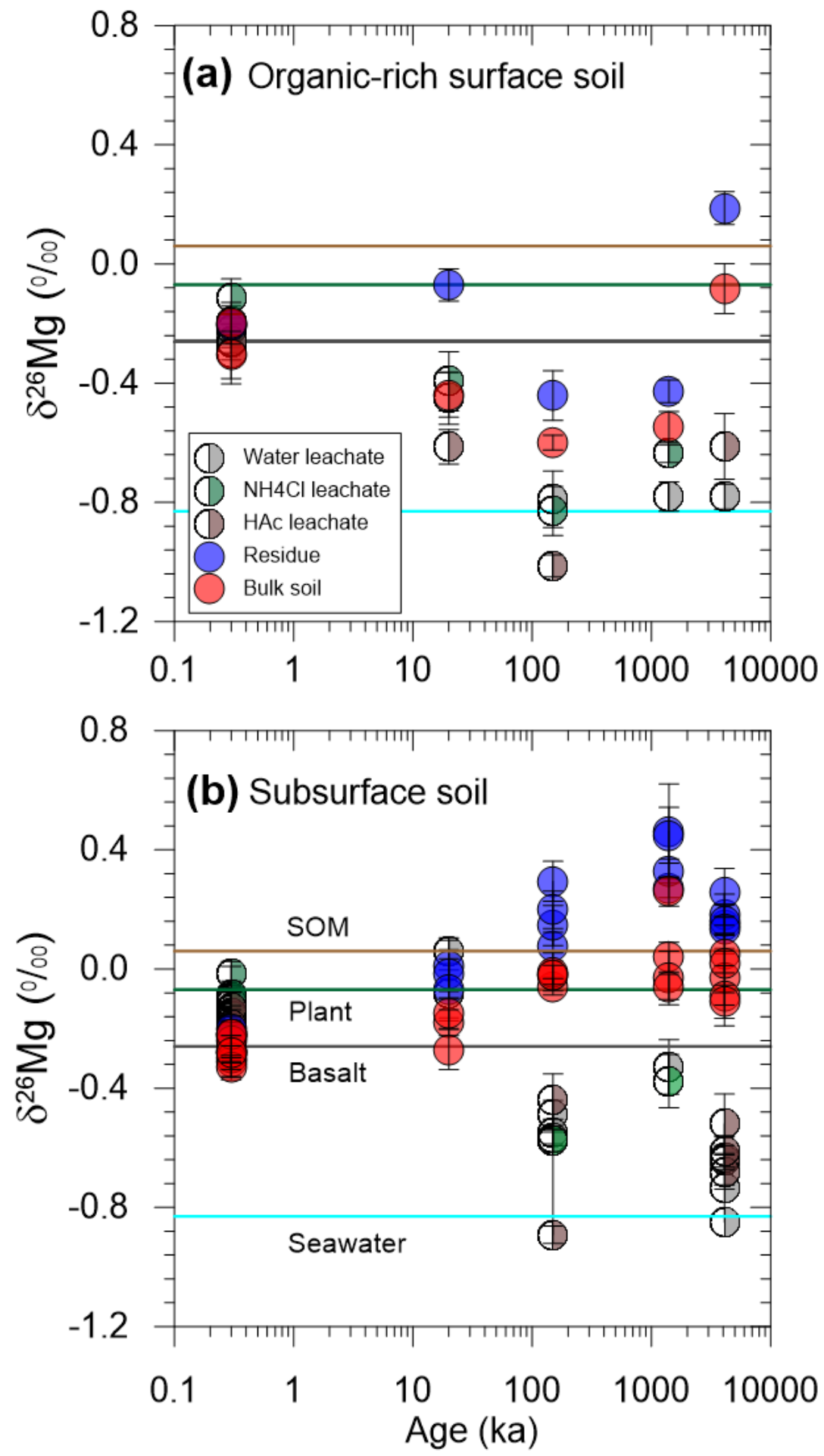

Fig. 4. Ryu et al. 

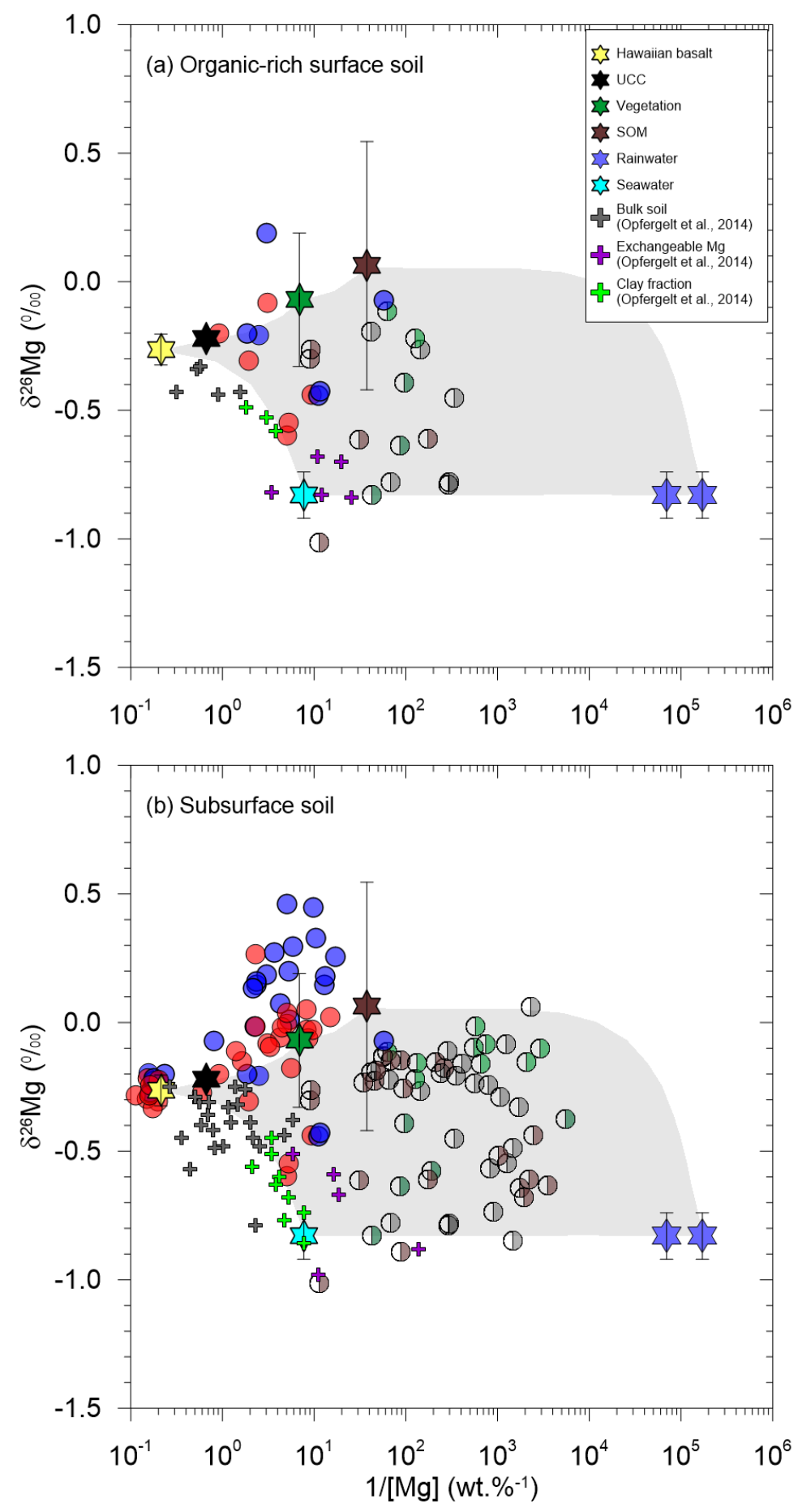

Fig. 5. Ryu et al. 


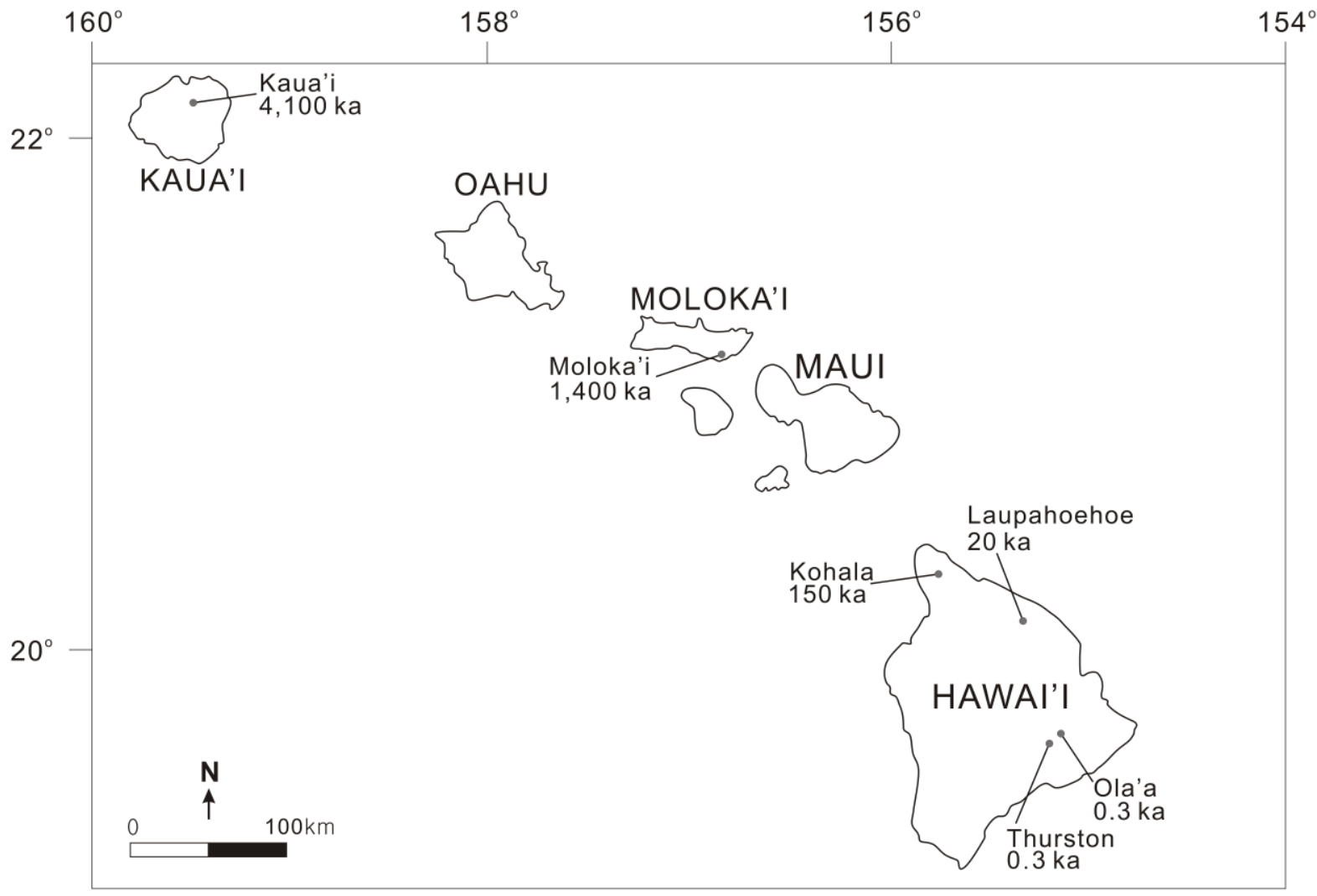

Fig. S1. Ryu et al. 


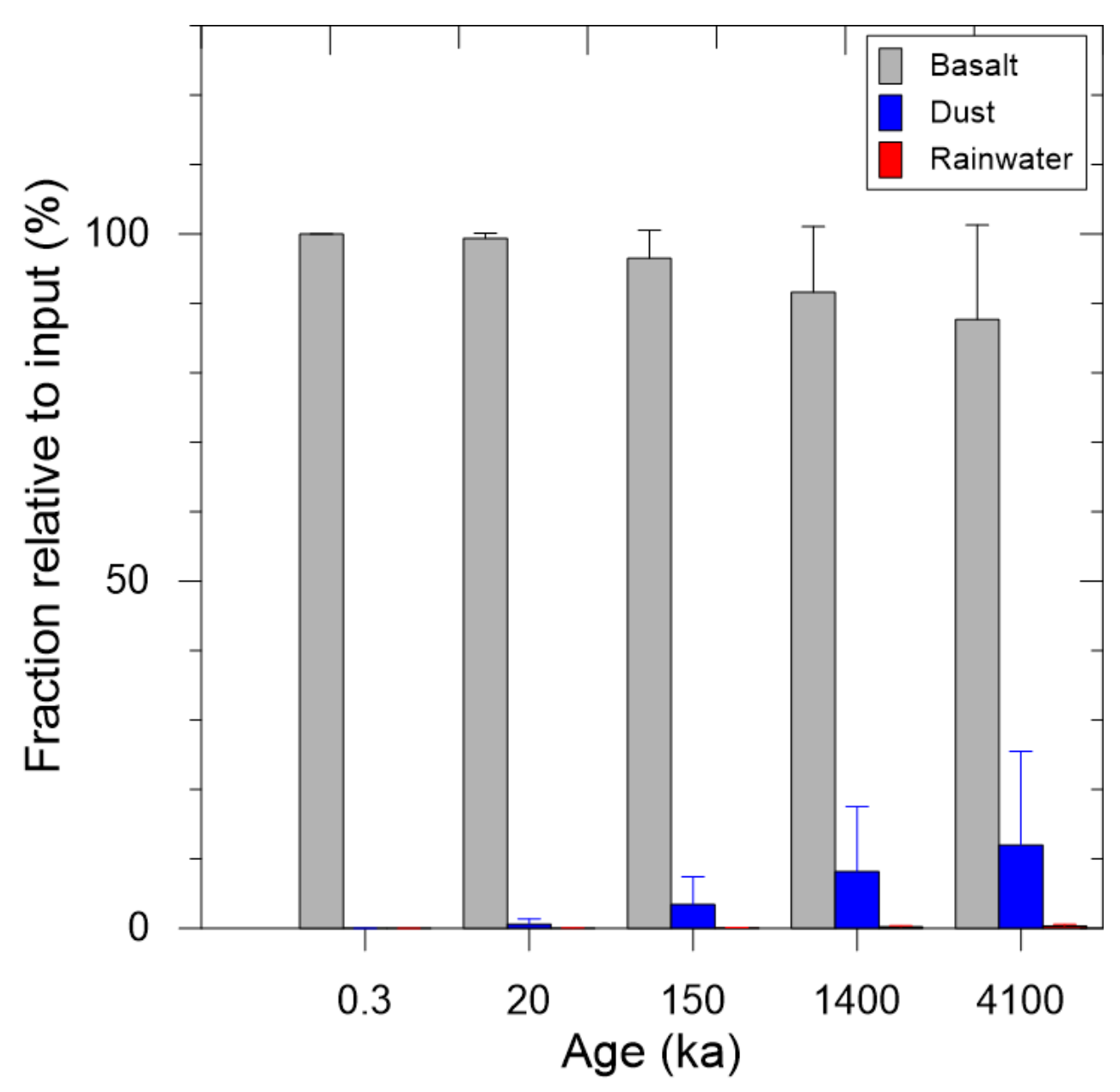

Fig. S2. Ryu et al. 